Geobios, 2022.

https://doi.org/10.1016/j.geobios.2021.12.001

\title{
Holocene history of peatland communities of central Rif (Northern Morocco)
}

Serge D. Muller ${ }^{\text {a, }}$, Amina Daoud-Bouattour ${ }^{\text {b,c }}$, Séverine Fauquette ${ }^{\text {a }}$, Marion BottollierCurtet ${ }^{\mathrm{d}}$, Nabil Rifai ${ }^{\mathrm{e}}$, Mary Robles ${ }^{\text {a }}$, Er-Riyahi Saber ${ }^{\mathrm{f}}$, Mohammed El Madihi ${ }^{\mathrm{g}, \mathrm{h}}$, Saïd Moukrim 'g, Laila Rhazi ${ }^{g}$

${ }^{a}$ Institut des Sciences de l’Évolution (ISEM), Univ. Montpellier, CNRS, IRD, EPHE, 34095 Montpellier cedex 05, France

${ }^{\mathrm{b}}$ Département de Biologie, Faculté des Sciences de Tunis, Université Tunis El-Manar, 2092 Tunis, Tunisia

${ }^{\mathrm{c}}$ LR18ES13 Biogéographie, Climatologie appliquée et Dynamiques environnementales, Faculté des Lettres, des Arts et des Humanités de Manouba, Université de la Manouba, 2010 Manouba, Tunisia

${ }^{\mathrm{d}}$ Les Écologistes de l'Euzière, Domaine de Restinclières, 34730 Prades-le-Lez, France

${ }^{\mathrm{e}}$ Département des Eaux et Forêts, 3 rue Harroun Errachid-Agdal, Rabat, Morocco

${ }^{\mathrm{f}}$ Département de Géographie, Faculté des Lettres et Sciences Humaines, Université Moulay Ismail, BP 11202,

Zitoune Meknès, Morocco

${ }^{\mathrm{g}}$ Université Mohammed V de Rabat, Faculté des Sciences, Centre de Recherche Biotechnologies Végétale et Microbienne, Biodiversité et Environnement, 4 avenue Ibn Battouta BP 1014 RP, Rabat, Morocco

${ }^{\mathrm{h}}$ Institut de recherche pour la conservation des zones humides méditerranéennes, Tour du Valat, Le Sambuc, 13 200 Arles, France

*Corresponding author. E-mail address: serge.muller@umontpellier.fr (S.D. Muller).

\begin{abstract}
The Maghreb's Mediterranean coastal edge is home to many peatlands with boreal floristic affinities and high conservation value. The work aims at investigating the Holocene developmental history of these wetlands in Northern Morocco, based on pollen record, losson-ignition and radiocarbon dating. First, the comparison between modern pollen spectra and present-day hydrophytic vegetation makes it possible to identify the local pollen signal. Second, while peatlands have existed in the Rif for at least 13,000 years, their initiation mostly by paludification extends throughout the Holocene. Their plant composition remains relatively unchanged for millennia, but swamp undergrowth could locally experience changes in taxa dominance. Mid- to late-Holocene sedimentation changes appear to result from the human-induced regional decline of cedar. The major changes experienced by wetlands occurred recently, due to clearing, burning and overgrazing. Effective conservation policies should be urgently implemented in order to save the last relict peatlands of Northern Morocco.
\end{abstract}

Keywords: Late Quaternary - Pollen - Maghreb - Mediterranean Wetland - Anthropisation Conservation 


\section{Introduction}

The Mediterranean coastal fringe of the Maghreb is home to peatlands with boreal vegetation affinities, located at the rear edge of their main distribution area, which extends from Mediterranean mountains to Scandinavia (Joosten et al., 2017). These peat-forming wetlands are located in the wettest northern regions of the Maghreb (Fig. 1(A)): (1) in Morocco, the Loukkos Valley close to Larache and the Jebala Range of the Rif; (2) in Algeria, the high coastal reliefs from Edough to Akfadou, and the sandy coastal complexes of El Kala National Park and Guerbès-Senhadja; and (3) in Tunisia, the Kroumiria mountain range and the hill region of Mogods. These regions are all included in biodiversity hotspots: the Betic-Rifan complex in the west (Médail and Quézel, 1999) and the Kabylies-NumidiaKroumiria complex in the east (Véla and Benhouhou, 2007).

North African peatland habitats include alder swamps that occur in the three countries of the Maghreb (Meddour and Laribi, 1999), Sphagnum fens that are particularly developed in Northern Morocco (Dahlgren and Lassen, 1972; Muller et al., 2010, 2011), and peaty heathlands of Erica scoparia that are known in Northern Tunisia (Ferchichi-Ben Jamaa et al., 2010) and were recently identified as an ancient, long-living community in Northeastern Algeria (Ghit et al., 2018). Despite the unquestionable ecological, biogeographical and economic values of these habitats (e.g. Bragg and Lindsay, 2003; Andersen et al., 2016), very few dedicated palaeoecological studies focus on the Mediterranean region. Whereas North African peatlands have long been studied in order to reconstruct past regional vegetation dynamics (Reille, 1977; Ben Tiba and Reille, 1982; Damblon, 1991; Salamani, 1991, 1993; Stambouli-Essassi et al., 2007; Benslama et al., 2010; Muller et al., 2015), their own vegetation and sedimentation dynamics have only been investigated in Northeastern Algeria (Ghit et al., 2018). As a result, the Holocene origin and history of North African peatlands and swamps are virtually entirely unknown.

The study of Reille (1977) provides a number of pollen diagrams for the Jebala Range (Rif, Morocco). These diagrams, while poorly dated, contain valuable information about the past local vegetation of the studied wetlands, and raises some questions. In particular, one intriguing feature of these diagrams is the heterogeneous record of cereal-type pollen that is high (5-10\%) and almost continuous in some sites, but not in others. While noting that this pollen type includes also wild taxa, Reille (1977) interpreted the high percentages found at the base of the pollen diagram of Bartete (initially named Arbatète), as translating an ancient cultural episode. This interpretation agrees with recent findings (Ballouche and Marinval, 2003; Zielhofer and Linstädter, 2006; Zapata et al., 2013), but poses a problem with respect to another record in a site located $1200 \mathrm{~m}$ away, on the same aspect (Muller et al., 2015).

The present study aims at (1) characterising the pollen record of wetland plant communities of the Jebala Range and (2) reconstructing the origin and past history of the peat-forming wetlands of Rif. First, we established a model of pollen representation of peatforming plant communities based on surface pollen data and associated phytosociological relevés, both collected in various regional wetlands representing all the regional wetland habitats. In addition, a biometric study of selected Poaceae pollen was undertaken in order to resolve the problem of the long-term cereal-type pollen record of Reille (1977). Second, this present-day model was used to interpret past local pollen records from Reille (1977) and from two new cores taken from Jbel Bou Hachem, the main relief of Jebala Range. 


\section{Material and methods}

\subsection{Geographical, geological and biogeographical setting}

The Rif mountain range, which forms the Gibraltar Arc with the Betic Range, began to rise during the Oligocene from the convergence of Africa and Europe (Chalouan et al., 2008). From the northeast to the southwest (Romagny et al., 2014), it includes the following:

- an internal zone along the Mediterranean coast consisting essentially of more or less metamorphosed continental basement (Sebtides and Ghomarides nappes) and sedimentary covers composed of limestone rock (the so-called Rif Dorsal);

- the Maghrebian Flysch Basin Units comprising a nappe stack of predominantly turbiditic deposits that constitute the Jebala Range;

- an external zone corresponding to Triassic to Miocene formations of the African palaeomargin that was folded and thrust up during the Miocene collision.

Our samples come from the Jebala Range, where Jbel Bou Hachem, located northwest of Chefchaouen, constitutes the highest relief (1602 m asl; Fig. 1(B)). The major phytogeographic interest of this massif (Sauvage, 1958) in terms of forest diversity and wetland abundance, including remarkable Sphagnum fens (Dahlgren and Lassen, 1972; Muller et al., 2011), led to it being named a Site of Biological and Ecological Interest (SBEI) in 1996 and an Important Plant Area (IPA) in 2004, and its inclusion in the Intercontinental Mediterranean Biosphere Reserve (IMBR) in 2006 (Benabid, 2000; Taleb and Fennane, 2011).

Characterised by a humid to sub-humid bioclimate, the Rif harbours a variety of fragmentary forest ecosystems (Sauvage, 1958; Benabid, 2000; Ajbilou et al., 2006), organised in mosaic with deforested zones mainly occupied by Mediterranean scrublands (matorrals), degraded therophytic meadows and cultivated lands, including the production of kif (Cannabis sativa), whose expansion is provoking an on-going forest decline (Quézel and Barbero, 1990; Taiqui, 1997).

\subsection{Study sites and fieldwork}

Vegetation surveys, systematically associated with surface sediment sampling, were conducted in May 2010 and June 2012 on 13 wetlands located on 4 reliefs of the Jebala Range (Fig. 1(B); Table 1). All sites lay on sandstone with the exception of DAY2, which sits on limestone at the boundary between the Jebala Range and the Rif Dorsal. The botanical nomenclature follows Fennane et al. (1999, 2007, 2014), Dobignard and Chatelain (20102013) and Le Floc'h et al. (2010).

New sediment cores (Fig. 1(B)) were taken from three wetlands (BAR, $248 \mathrm{~cm}$; MF1b, $132 \mathrm{~cm}$; MF3, $530 \mathrm{~cm}$ ) with a 50 x $5 \mathrm{~cm}$ Russian sampler, and conserved in plastic film until sampling in the laboratory. BAR (Bartete) is a cultivated peaty meadow on a flat, gently sloping surface at the head of a watershed. The site was previously studied as 'Daya Arbatète' by Reille (1977), who postulated a pollen-based Early Holocene age for basal sediment layers and found high Cereal-type pollen percentages that he interpreted as ancient cultural episodes. MF1 (Maison Forestière-1) is a roughly circular fen of 0.2 ha, located 300 $\mathrm{m}$ below the Bou Hachem forest house and covered by a continuous Sphagnum carpet. MF3 (Maison Forestière-3), located 1200 m north of MF1, includes a highly degraded alder swamp and a pond covered by aquatic floating plants. Both sites are neither cultivated nor 
drained, but they are overgrazed by cows and sheeps. This site was previously studied under the name 'Mare à sphaignes du jbel Bou Hachem' by Reille (1977). MF1 and MF3 surroundings are currently dominated by bracken (Pteridium aquilinum), the zeen oak (Quercus canariensis) forest having been cut down in the early 2000s.

\subsection{Laboratory work and data analysis}

Modern samples study. After chemical treatment (Berglund and RalskaJasiewiczowa, 1986) including a 36-hour digestion with 70\% hydrofluoric acid, the 13 surface sediments were used to identify the local pollen signal and the local pollen indicators, based on a comparison with floristic relevés. Pollen slides were mounted in glycerol. Ascendant hierarchical classifications (AHC) were carried out on phytosociological relevés comprising 13 sites and 149 taxa, using the Paired Group Clustering (UPGMA) and the Chord distance with Past 4.03 (Hammer et al., 2001).

Palaeoecological study. First, we took $1-\mathrm{cm}^{3}$ samples every $2 \mathrm{~cm}$ for loss-on-ignition (LOI) on the three studied cores (BAR, MF1b and MF3). LOI measurements were made by re-weighing the samples after five hours at $550^{\circ} \mathrm{C}$ in an oven (Heiri et al., 2001). Second, we took $1-\mathrm{cm}^{3}$ samples every $2 \mathrm{~cm}$ for pollen analysis on MF1b and MF3 cores. Palynological analyses of sediments were completed after chemical treatments (see above). Pollen percentages were based on sums excluding Pteridophyte spores and the most over-represented tree taxa (Alnus, Quercus canariensis-type) to reveal local plant dynamics. Total pollen sums exceed 500 grains, except for some poor levels. Pollen nomenclature follows Birks and Birks (1980) and Faegri and Iversen (1989). Pollen diagrams were constructed with R-Rioja package 0.9-26 (Juggins, 2020), and zonation was realised with the program Coniss (Grimm, 1987).

In order to compare our new palynological data with the ones of Reille (1977), we homogenized the pollen nomenclature, and calculated the percentages on the same basis. We also realized and radiocarbon-dated a new core in the Bartete peatland in order to provide a chronological framework to the undated Reille (1977)'s diagram. The new core was collected in the same area than the Reille (1977)'s one, according to the provided map: both cores measure the same length and their composition are very similar.

Representation indices. Indices of association (A), under-representation (U) and over-representation $(\mathrm{O})$ were calculated using presence/absence data from the vegetation survey (Davis, 1984; Hjelle, 1997; Bunting, 2003). These indices (here given as percentages) are defined as follows:

$$
\begin{aligned}
& \text { - } \mathrm{A}=\mathrm{B} 0 * 100 /(\mathrm{P} 0+\mathrm{P} 1+\mathrm{B} 0) \\
& \text { - } \mathrm{U}=\mathrm{P} 1 * 100 /(\mathrm{P} 1+\mathrm{B} 0) \\
& \text { - } \mathrm{O}=\mathrm{P} 0 * 100 /(\mathrm{P} 0+\mathrm{B} 0)
\end{aligned}
$$

where $\mathrm{B} 0$ is the number of samples in which both the pollen type and its associated plant are present; $\mathrm{P} 0$ is the number of samples in which the pollen type is present in the surface sample but not the plant taxa; and P1 is the number of samples in which the pollen type is not present in the surface sample but the plant is present in the vegetation. The representation indices are used for determining the association and representation of each taxon, as follows:

- Strongly associated taxa: A > 65\%; 
- Associated taxa: $50 \%<\mathrm{A}<65 \%$;

- Weakly associated taxa: low A values and relatively high values for both $\mathrm{U}$ and $\mathrm{O}$;

- Not-associated taxa: $\mathrm{A}=0$, and high $\mathrm{O}$ and $\mathrm{U}$ values;

- Over-represented taxa: low A values, high $\mathrm{O}$ values and $\mathrm{U}=0$.

Suchéras-Marx et al. (2019) note the recurrent lack of confidence intervals associated with empirical proportions or percentages in micropaleontological studies. Representation indices are effectively usually given without confidence intervals (e.g. Mazier et al., 2006; Brun et al., 2007; Amami et al., 2010). As Davis indices are, up to a factor 100, binomial proportions with, in our case, denominator consistently less than 40, we followed guidelines from Brown et al. (2001) and computed Wilson confidence intervals at level $\alpha=0.1, C I_{A}, C I_{U}$, and $C I_{O}$ for $\mathrm{A}, \mathrm{U}$, and $\mathrm{O}$ respectively:

$$
\begin{gathered}
C I_{A}=\frac{B_{0}+\kappa^{2} / 2 \pm \kappa \sqrt{B_{0}\left(1-\frac{B_{0}}{B_{0}+P_{0}+P_{1}}\right)+\frac{\kappa^{2}}{4}}}{B_{0}+P_{0}+P_{1}+\kappa^{2}} \\
C I_{U}=\frac{P_{1}+\kappa^{2} / 2 \pm \kappa \sqrt{P_{1}\left(1-\frac{P_{1}}{B_{0}+P_{1}}\right)+\frac{\kappa^{2}}{4}}}{B_{0}+P_{1}+\kappa^{2}} \\
C I_{A}=\frac{P_{0}+\kappa^{2} / 2 \pm \kappa \sqrt{P_{0}\left(1-\frac{P_{0}}{B_{0}+P_{0}}\right)+\frac{\kappa^{2}}{4}}}{B_{0}+P_{0}+\kappa^{2}}
\end{gathered}
$$

where $\kappa=z_{\alpha / 2}$, the $100(1-\alpha / 2)^{t h}$ percentile of the standard normal distribution.

Dating. Unfortunately, the sediments contain no macrofossils except some wood charcoals, two of which being identified and radiocarbon-dated. Consequently, the chronology of the three studied cores is based on radiocarbon dating obtained from bulk sediment and macrocharcoal. Calibrated ages (cal. BP, i.e. calendar years before the present) were computed with Calib 8.1.0 (Stuiver and Reimer, 1993) using the calibration dataset IntCal20 (Reimer et al., 2020).

Habitat typology. The typology of wetland habitats was based on an ascendant hierarchical classification (paired group clustering, Chord similarity measure) carried out with Past 4.03 (Hammer et al., 2001) and performed on phytosociological relevés (13 sites) comprising only the species encountered at least three times ( 80 species).

Biometric data. Biometric measurements were made on Poaceae pollen slides from the pollen collection of the Institut des Sciences de l'Evolution, Université de Montpellier. As noted by Faegri and Iversen (1989), the medium used to mount the observation slides (glycerol or silicone oil) influences grain size. They also note that conversion factors vary between 1.1 and 1.3 for grain size and between 1.1 and 1.5 for pore size (pollen mounted in glycerol being larger than pollen mounted in silicone oil). The pollen collection that was used and all previous published keys except Andersen's (1979) refer to pollen mounted in glycerol. The studied pollen slides are (the number of slides, the collect location and the plant name (when different from the accepted name) are given into square brackets): Avena barbata Pott ex Link subsp. wiestii (Steud.) Mansf. [20938, Sahara, A. alba var. wiestii]; Avena sativa L. subsp. sativa [4502, North America]; Bromopsis inermis (Leyss.) Holub subsp. inermis [4420, America, Bromus inermis]; Dactylis glomerata L. [23545, India]; Elytrigia campestris (God. 
\& Gren.) Carreras Martinez [28391, France, Elymus pungens]; Glyceria fluitans (L.) R.Br. [9092, India; 43407, Corsica]; Glyceria notata Chevall. [42804, 42807, Corsica]; Hordeum brevisubulatum (Trin.) Link [18973, Iran, H. turkestanicum]; Hordeum vulgare L. subsp. distichon (L.) Körn [42870, 42898, France]; Leymus condensatus (J.Presl.) Á.Löve [4504, loc. n.a., Elymus condensatus]; Phragmites australis (Cav.) Steud. [20828, Portugal, $P$. communis]; Schedonorus arundinaceus (Schreb.) Dumort. [30932, France, Festuca arundinacea]; Secale cereale L. [4164, Poland]; Thinopyrum elongatum (Host) D.R.Dewey [28390, Europe, Elymus elongatus]; Triticum aestivum L. subsp. aestivum [33268, France]; Triticum aestivum L. subsp. spelta (L.) Thell. [23311, France, T. spelta var. arduini; 23320, Europe, T. spelta; 31135, France, T. spelta; 31305, France, T. spelta var. coeruleum]; Triticum compactum Host [34465, Europe]; Triticum turgidum L. subsp. dicoccum (Schrank) Thell. [31130, France, T. dicoccum]; Triticum turgidum L. subsp. durum (Desf.) Husn. [22973, Algeria, T. durum; 31313, loc. n.a., T. durum; 46850, France, T. durum var. primadur; 46851, France, T. durum var. arcour]; Triticum turgidum L. subsp. turgidum [43408, France]; Zea mays L. [46478, USA].

\section{Results}

\subsection{Richness and typology of wetland habitats}

The vegetation surveys carried out in 13 wetlands of the Jebala Range led to the identification of 148 species, 64 of which encountered only once (Table 2). Floristic richness ranges from 22 to 52; the maximum corresponds to the site MF3 that includes two contiguous habitats (a swamp and a pond). Our data make it possible to distinguish 3 main types of habitats (fen, temporary pond, alder swamp), and 2 less common ones (Sphagnum pond, alkaline lake) (Fig. 2):

- Fens. The most abundant habitat is represented by fens that accumulate organic clay and occur throughout the Jebala Range: Jbel Bou Hachem (MF1, MF2), Jbel Khezana (ABF, BAR, BAZ) and Jbel Sougna (TANT). These all harbour dense lawns of herbaceous hydrophytic plants (Baldellia repens, Carex distans, C. echinata, Dactylorhiza maurusia, Eleocharis multicaulis, Juncus bulbosus, Lotus pedunculatus, Lysimachia tyrrhenia (=Anagallis crassifolia), Lythrum junceum, Myosotis welwitschii, Potamogeton polygonifolius, Potentilla erecta, Silene laeta), often integrating Aulacomnium palustre and Sphagnum auriculatum carpets. When present, margins are covered by low scrubs of Calluna vulgaris, Erica ciliaris, Genista ancistrocarpa and Myrtus communis.

- Temporary ponds. The Mediterranean temporary habitats also occur on the Jebala's three main reliefs: Jbel Bou Hachem (MF3, TAY1), Jbel Khezana (BOU) and Jbel Sougna (MAR), which harbour Eleocharis palustris, Glyceria spicata, Isoetes velata and Juncus heterophyllus accompanied by a therophytic community including Baldellia ranunculoides, Callitriche spp., Cicendia filiformis, Galium palustre subsp. elongatum, Gratiola mauretanica, Helosciadium inundatum, Illecebrum verticillatum, Juncus bufonius, J. pygmaeus, Lotus hispidus, Lythrum borysthenicum, Poa annua, Radiola linoides, Ranunculus spp., Serapias spp. and Trifolium spp.

- Alder swamps. Only two relictual alder swamps were found, both of which are located on Jbel Bou Hachem: one is healthy (MF5), while the second is strongly degraded (MF3). Alnus glutinosa is associated with Frangula alnus subsp. baetica, Hedera helix subsp. 
maroccana, Ilex aquifolium, Prunus lusitanica subsp. lusitanica, Rubus ulmifolius, Salix atrocinerea and $S$. pedicellata, which dominate an undergrowth composed of Athyrium filix-femina, Blechnum spicant, Carex remota, Lobelia urens, Ludwigia palustris, Lysimachia tyrrhenia, Potamogeton polygonifolius and Potentilla erecta.

- Sphagnum pond. This wetland type is found in only one site, which is located on Jbel Bou Hachem: MF4 lies in a small depression inundated in winter and spring. Carpets of Sphagnum auriculatum, which are submerged during part of the year, virtually cover the thin clayey soil. The site also includes Baldellia ranunculoides, Danthonia decumbens, Eleocharis spp., Exaculum pusillum, Gratiola mauretanica, Juncus bulbosus and Potentilla erecta.

- Alkaline lake. The lake of Dayla-2 (DAY2), variously named Anasser (Reille, 1977) and Aanasser (Cheddadi et al., 2015) is located on the southern slope of the Jbel Tizirene, a limestone relief that belongs to the limestone Rifan Dorsal. It harbours a floating mat of high helophytes, including Phragmites australis, Sparganium erectum and Typha latifolia. The associated vegetation is quite different from that encountered in the Jebala Range because of the lack of the strictly calcifuge taxa and the presence of some species not found in the sandstone reliefs (Carex pseudocyperus, Dorycnium rectum, Lemna minor, Lycopus europaeus, Sparganium erectum, Typha latifolia, Verbena supina, Veronica anagalloides). The lake of Dayla-2 is very close to the lake of Dayla-1 (DAY1) that was studied by Reille (1977) but not sampled here for surface pollen.

\subsection{Poaceae pollen measurements}

The results of the pollen measurements of selected Poaceae species (Table 3) allow distinguishing the following groups (the studied taxa are given into brackets):

- Zea (Zea mays): grain > $100 \mu \mathrm{m}$

- Secale (Secale cereale): grain 60-100 $\mu \mathrm{m}, \mathrm{P} / \mathrm{E}>1.2$, lateral pore

- Triticum (Triticum aestivum subsp. aestivum, T. aestivum subsp. spelta, T. turgidum subsp. dicoccum, T. turgidum subsp. durum, T. turgidum subsp. turgidum): grain 60-100 $\mu \mathrm{m}, \mathrm{P} / \mathrm{E}<1.2$, (sub)apical pore

- Glyceria-type (Avena sativa subsp. sativa, Glyceria fluitans, G. notata, Hordeum vulgare subsp. distichon): grain 40-60 $\mu \mathrm{m}, \mathrm{A}=9-18 \mu \mathrm{m}$

- Poaceae = wild grass-type (Avena barbata subsp. wiestii, Bromopsis inermis subsp. inermis, Dactylis glomerata, Elytrigia campestris, Hordeum brevisubulatum, Leymus condensatus, Phragmites australis, Schedonorus arundinaceus, Thinopyrum elongatum): grain $<50 \mu \mathrm{m}, \mathrm{A}<12 \mu \mathrm{m}$.

with A, Annulus width; P/E, Polar diameter/Equatorial diameter.

\subsection{Present-day hydrophytic pollen record}

The local pollen richness (60 pollen and spore taxa) represents $40.5 \%$ of the hydrophytic species richness (148 species belonging to 97 genera and 53 families) of the wetlands of the Jebala Range. Representation indices based on presence-absence data (Davis, 1984; Hjelle, 1997; Bunting, 2003; Amami et al., 2010) help to characterise the association between pollen and vegetation for 45 taxa present in both plant and pollen datasets: 27 taxa are weakly to strongly associated and 18 are overrepresented (Table 4). Both vegetation 
surveys (Table 2) and the diagram based on modern pollen data (Fig. 3) are likely to provide complementary clues for discriminating good indicators of their local occurrence or of the local presence of their community. Indeed, they allow identifying good plant indicators (plants more or less restricted to a particular community) and comparing the respective values of vegetation and plant abundances (the representation indices only take in account the presence-absence). On the basis of this dataset, we identify the following taxa that can be used to reconstruct the different communities in the fossil record (strongly associated taxa and associated taxa noted in bold):

- Swamps: Alnus (A. glutinosa), Frangula (F. alnus), Ilex (I. aquifolium), Prunus-type ( $P$. lusitanica), Salix (S. atrocinerea, S. pedicellata), Dryopteris-type (Athyrium filix-femina, Blechnum spicant)

- Fens: Erica-type (E. ciliaris), Genista-type (G. ancistrocarpa), Alisma-type (Baldellia repens), Cyperaceae (Carex spp., Eleocharis multicaulis), Lobelia (L. urens), Lysimachia tenella-type (L. tenella, L. tyrrhenia), Sphagnum (S. auriculatum)

- Temporary ponds: Alisma-type (Baldellia ranunculoides), Cicendia/Exaculum $(C$. filiformis, E. pusillum), Glyceria-type (G. spicata), Lythrum borysthenicum-type ( $L$. borysthenicum, L. junceum, L. portula), Gratiola-type (G. mauretanica), Ranunculustype ( $R$. baudotii, $R$. ophioglossifolius), Isoetes (I. velata)

- Alkaline lake: Alisma-type (A. lanceolatum), Callitriche (C. stagnalis), Cyperaceae (Carex pseudocyperus), Montia (M. minor), Potamogeton-type (P. polygonifolius), Sparganium/Typha (S. erectum)

- Sphagnum pond: Genista-type (G. ancistrocarpa), Alisma-type (Baldellia ranunculoides), Cicendia/Exaculum (C. filiformis, E. pusillum), Cyperaceae (Carex distans, Eleocharis multicaulis, E. palustris, Isolepis cernua), Sphagnum (S. auriculatum)

\subsection{Radiocarbon dating and sediment composition}

The studied wetlands of Northern Morocco are called "peatlands", especially because of their vegetation typical of European peatlands (Dahlgren and Lassen, 1972; Muller et al., 2010, 2011). However, they generally do not accumulate a true peat, which should essentially be constituted of partially degraded plant remains. As shown by the Figure 4, the organicmatter content of the three studied cores is mainly less than $10 \%$ and never exceeds $50 \%$. The sediment accumulated should then be called organic or peaty clay. The weak organic content probably results from the Mediterranean climate that induced both a strong decomposition during the summer months and detritic inputs of mineral particles in autumn and spring. Moreover, the three studied sequences are highly heterogeneous and include intercalated layers of sand, suggesting past changes in the watershed vegetation cover.

The radiocarbon dates available for the Jebala Range are synthesized in Table 5. They reveal several periods of wetland initiation: $c a .13000 \mathrm{cal}$. BP (BAR, degraded alder swamp (Reille, 1977)), ca. 9000 cal. BP (BOU-BEK, pond (Cheddadi et al., 2016), ca. 5500-5000 cal. BP (MF1b, fen (Muller et al., 2015); MF3, alder swamp and pond) and ca. 2000-1000 cal. BP (DAY2, lake; MAR (Reille, 1977), pond; RHE1, swamp (Reille, 1977); TAN, lake (Reille, 1977)). Alder swamps and fens (BAR, MF1b, MF3) are globally older than ponds and lakes (DAY2, MAR, TAN) that only initiated in the last 2 millennia, but there is no absolute 
rule: the swamp RHE1 initiated around 1600 cal. BP, while the pond BOU/BEK initiated in the early Holocene at $c a .9000 \mathrm{cal}$. BP. Sediment accumulation rates (SAR) are also very different between both types of wetlands: with the exception of the swamp RHE1, fens and alder swamps present significantly lower SAR ( ca. $\left.0.2 \mathrm{~mm}_{\mathrm{yr}} \mathrm{yr}^{-1}\right)$ than ponds and lakes, which SAR is generally near $1 \mathrm{~mm} . \mathrm{yr}^{-1}$ and reaches $5.5 \mathrm{~mm} . \mathrm{yr}^{-1}$ in the central part of the alkaline lake DAY-2 (Table 1). Despite the heterogeneous sediment content of cores, the age-depth models (Fig. 4) reveal few changes of SAR, with the exception of the severe lowering of apparent SAR around $60 \mathrm{~cm}$ depth at BAR. This could result from a hiatus of sedimentation or more probably from human-triggered disturbances of the upper part of the sediment column. In the Bartete site, the Reille (1977)'s age was realised on a different core (Lv-635; BAR3) than ours (BAR). However, our chronology suggests that this age is too young, as is the one obtained in our sequence from a wood charcoal (Poz-51919; Muller et al., 2015).

The three sites show a decrease in organic matter (OM) content with depth due both to the process of decomposition and to the deposition of sand in the lower part of the sequences (below $114 \mathrm{~cm}$ at BAR, below $104 \mathrm{~cm}$ at MF1b and below $200 \mathrm{~cm}$ at MF3). Some sharp changes can be observed in relation with the nature of the sediment that primarily correspond to a transition from mineral (sand and clay) to more organic sediments (peaty clay or decomposed peat) that occur at $c a .780 \mathrm{cal} . \mathrm{BP}(78 \mathrm{~cm})$ at $\mathrm{MF} 3$, and later, around $440 \mathrm{cal}$. BP at MF1b $(36 \mathrm{~cm})$ and at BAR $(55 \mathrm{~cm})$. A detritic event is recorded by an abrupt lowering of OM content at a depth of $28 \mathrm{~cm}(\mathrm{ca} .310 \mathrm{cal}$. BP) in the MF3 sequence.

\subsection{Hydrophytic pollen data}

The local pollen diagrams of MF1b, MF3 and BAR are presented Figs. 5, 6 and 7, respectively.

\subsubsection{Maison forestière-1, core MF1b}

MF1b-Z1 (128-66 cm; 4900-1970 cal. BP). The lowest part of the sequence (Fig. 5) shows high percentages of unidentified pollen, which indicate poor preservation conditions possibly due to running water in an (open?) depression. The surprising association between aquatic taxa (Callitriche, Glyceria-type, Ranunculus-type) and Sphagnum suggests a waterlogged habitat resembling the Sphagnum pond MF4.

MF1b-Z2 (66-34 cm; 1970-390 cal. BP). The increase in pollen percentages of Cyperaceae, Potentilla, Salix and Sphagnum, coupled with a progressive increase in OM content, attests to the onset of a fen plant community that probably limited the water runoff.

MF1b-Z3 (34-0 cm; 390-0 cal. BP). The abrupt increase in Cyperaceae linked with the appearance of Alisma-type, Juncaceae, Lysimachia tenella-type and Lythrum borysthenicumtype reflects the recent constitution of the site's present-day plant cover.

\subsubsection{Maison forestière-3, core $M F 3$}

MF3-Z1 (512-328 cm; 5300-3800 cal. BP). Alnus dominates the swamp surrounding the pond (Fig. 6). The undergrowth is mainly constituted by Ilex, associated with Frangula. The occurrences of Apiaceae, Cyperaceae, Glyceria-type and Ranunculus-type translate the aquatic community inhabiting the waterhole. 
MF3-Z2 (328-184 cm; 3800-2220 cal. BP). The increases of Cyperaceae and Sphagnum may reveal internal modifications in swamp structure, also revealed by the replacement of Ilex by Frangula at the end of the zone. Apiaceae and Callitriche could translate either the pond's aquatic vegetation or the swamp's herbaceous undergrowth.

MF3-Z3 (184-88 cm; 2220-890 cal. BP). The ongoing swamp transformation is marked by the lowering of Alnus and Frangula percentages associated with the expansion of Salix. Conversely, the aquatic vegetation underwent some changes: Cyperaceae probably constituted a riparian belt encircling the pond, while Glyceria-type and Ranunculus-type developed in the open-water zone. The alder swamp was probably less closed than in the past, but remains home to a rich flora including Frangula, Ilex, Prunus-type, Dryopteris-type, Osmunda and Sphagnum.

MF3-Z4 (88-0 cm; 890-0 cal. BP). The decrease in Salix attests the local decline of willow groves, just before the definitive opening of the alder swamp. The more regular pollen record of aquatic plants (Alisma-type, Glyceria-type, Juncaceae, Ranunculus-type, other aquatics) could translate either the diversification of pond vegetation or to it being better recorded in less degraded sediments.

\subsubsection{Bartete, BAR}

The ages proposed below for the sequence of Reille (1977) are inferred from our core taken in 2012 at the same location (Fig. 7). Because they have not been made on the same sediment sequence, we only give putative ages rounded per 500 years.

BAR-Z1 (240-145 cm; ca. 12500-6500 cal. BP). The basal high percentage of Alnus suggests that the sediment-accumulating swamp initiated within a pre-existing alder riparian forest. The lack of details of Reille (1977)'s diagram concerning hydrophytic taxa makes it difficult to specify the composition of this habitat, but the occurrence of Apiaceae and Ranunculaceae could reflect the presence of waterlogged places inside the swamp or on its edge.

BAR-Z2 (145-35 cm; ca. 6500-50 cal. BP). Cedrus increase reveals the development of a cedar forest around the swamp. The dense canopies of both cedar forest and alder swamp probably filtered between 6500 and $3000 \mathrm{cal}$. BP the regional pollen input (Tauber, 1965), here characterised by the curve Other taxa, modifying swamp composition (more Salix, less Ranunculaceae).

BAR-Z3 (35-0 cm; ca. 50-0 cal. BP). The abrupt decrease of Alnus at $35 \mathrm{~cm}$ deep reflects the disappearance of the local alder swamp and the constitution of the present-day cultivated peat meadow. The two modern radiocarbon ages obtained from two different core segments just above and below $50 \mathrm{~cm}$ in depth, and the one of $1010 \pm 50 \mathrm{cal}$. BP obtained by Reille (1977) on the BAR3-1977 core (Table 5) largely below the fall of the Alnus curve, make it possible that the swamp was cleared and the site cultivated only recently, perhaps even in the $20^{\text {th }}$ century. The recent increase in Cyperaceae, Lysimachia and Lythrum reveals the constitution of the modern plant community and the rise in Plantago probably indicates that surrounding shrublands were grazed.

\section{Discussion}

\subsection{Unravelling Glyceria from other Poaceae pollen types}


Despite the very homogenous monoporate pollen morphology of the Poaceae family, a number of keys have been proposed, with different appreciations of the few available diagnostic features (e.g., Firbas, 1937; Erdtman, 1943; Grohne, 1957; Beug, 1961, 2004; Andersen, 1979; Küster, 1988; Faegri and Iversen, 1989; see Tweddle et al., 2005 for a detailed review of these works). Most of the recent studies have attempted to discriminate cereals from wild grasses taking morphometric and statistical approaches, but they have failed to give univocal diagnostic characters (Tweddle et al., 2005; Joly et al., 2007). Nevertheless, Tweddle et al. (2005) show that a more reliable identification can be achieved by combining the approaches of Andersen (1979) and Küster (1988), and Joly et al. (2007) provide a practical key for discriminating cereals from wild grasses, with very useful indications of the degree of confidence of the attribution of some taxa to each group.

Our results confirm the distinction of Zea with a lower threshold of $100 \mu \mathrm{m}$, of Secale based on its large size $(60-100 \mu \mathrm{m})$ and its specific morphology, and of Cerealia-type (cerealtype) that is comprised between 60 and $100 \mu \mathrm{m}$. They moreover suggest that Cerealia-type is restricted to the genus Triticum, since Avena and Hordeum present smaller pollen grains.

The large size of Glyceria pollen leads to it being generally included in the "cerealtype". Erdtman (1943) incorporated it in its "intermediate group" (grain 32-35 $\mu \mathrm{m}$ ), defined by the shape of cereals and by the size of wild grasses, but the dimensions given are not consistent with our measurements (Table 3). Andersen (1979) included Glyceria in its "Hordeum group" (grain 38-54 $\mu \mathrm{m}$, annulus 10-13 $\mu \mathrm{m}$ ), and Joly et al. (2007) in its "wild grass-type" (grain $<47 \mu \mathrm{m}$, annulus $<11 \mu \mathrm{m}$ ). Those two conceptions are more or less consistent with Küster (1988), who defined a "Glyceria-type" (grain 40-80 $\mu$ m, annulus diameter lower than twice the pore diameter, with a diffuse outer boundary) including several wild grasses (Anthoxanthum, Elymus, Holcus, Hordelymus, Phragmites, Setaria, Spartina). Our results support the definition of the "Glyceria-type", but with some discrepancies with the Küster (1988)'s conception: the type, which includes the cultivated Avena sativa and Hordeum vulgare subsp. distichon, is characterised by a ratio annulus/pore $>2$ and an annulus width of (7)9-18 $\mu \mathrm{m}$ (Table 3). Surprisingly, our measurements are not consistent with the annulus size given by Andersen (1979) $(10-13 \mu \mathrm{m})$ and Joly et al. $(2007)(<11 \mu \mathrm{m})$.

The Poaceae pollen type, which corresponds to wild grass-type, includes all Poaceae species that cannot be classified in a specific group. It is generally defined first by a grain size of less than 30(40) $\mu \mathrm{m}$ (Erdtman, 1943), $40 \mu \mathrm{m}$ (Küster, 1988; Faegri and Iversen, 1989), $44 \mu \mathrm{m}$ (Andersen, 1979) or $47 \mu \mathrm{m}$ (Joly et al., 2007). With the exception of Erdtman (1943) who notes a pore $<2 \mu \mathrm{m}$ with no annulus, most published keys give an upper threshold value of 10-11 $\mu \mathrm{m}$ for annulus (Andersen, 1979; Faegri and Iversen, 1989; Joly et al., 2007). Our biometric data, while concerning few wild species, suggest raising the upper threshold values of annulus to $12 \mu \mathrm{m}$ and of the grain size to $50 \mu \mathrm{m}$. This type consequently includes a significant part (24\%) of the taxa included in Glyceria-type, implying its probable systematic underestimation in pollen counts.

This calls into question the reliability of the past pollen record of cereals. For example, the Cerealia-type pollen $(c a .50 \mu \mathrm{m})$ record from Lake Acıgöl in southwestern Turkey has recently been interpreted as reflecting the appearance of proto-cereals over the past 2.3 million years (Andrieu-Ponel et al., 2021). According to our results, only pollen grains larger than $60 \mu \mathrm{m}$ can be attributed with certainty to Cerealia-type, and probably even to Triticum. 
This suggests that such a record in a lacustrine environment could well have come from riparian populations of aquatic wild Poaceae like Glyceria spp., known to tolerate brackish water (e.g., Fennane et al., 2014), and that the decreasing trend of Cerealia-type percentages at Lake Acıgöl could translate the progressive salinization of the lake.

\subsection{Pollen representation of peat-forming plant communities of Northern Morocco}

The plant and pollen richness are evaluated in the wetlands of the Jebala Range at 148 species and 60 taxa, respectively, which allows calculating a loss of information of $\mathrm{ca}$. $60 \%$. Despite this well-known bias concerning species diversity in pollen records (Odgaard, 1999), most of the keystone species of the main wetland plant communities are well recorded, making it possible to discern them in pollen spectra.

The swamps of the Rif are structured mainly by Alnus glutinosa, the most often associated with Frangula alnus, Ilex aquifolium and, locally, Osmunda regalis. Alder pollen percentages exceed 10\% in only four sites: two of which (MF3 and MF5) house it, the two others (BAR and BAZ) do not (Fig. 3). BAR and BAZ, currently cultivated, are close together and located at the top of a watershed where Alnus is abundant in riparian situation. Its important pollen record in the pollen sequence of BAR (Fig. 7) (Reille, 1977) indicates that alder reached the site during the Holocene and disappeared from it, only some decades ago. The pollen surface assemblage then probably records the last local alder trees before clearing. The Alnus pollen record thus appears as a reliable indicator of its past local presence. The pollen records of Frangula, Ilex and Osmunda, while weak, are associated with high pollen percentages of Alnus, and are thus supplementary indicators of alder swamps.

Fens and the alkaline lake house numerous Cyperaceae, whose most abundant species belong to the genera Carex and Eleocharis, locally mixed with Cyperus longus, Isolepis spp. and Pycreus flavescens. They also include some aquatic Apiaceae (Helosciadium inundatum, $H$. nodiflorum, Oenanthe lachenalii). Both families, when associated in pollen records, appear to be good markers of these two habitats (Fig. 3). The pollen record of ligneous plants, which appear to be more diversified in fens than in the alkaline lake, makes it possible to distinguish them. Indeed, Calluna, Erica-type, Genista-type, Prunus-type and Salix are commonly recorded in surface pollen spectra from fens, whereas only Erica-type is present in DAY2 pollen record (Fig. 3). Since Sphagnum is a regular component of fens, its spore record is also useful for recognising this habitat.

Open water holes, such as ponds (BOU, MF3, TAY1) and alkaline lakes (DAY1, DAY2), house the aquatic herb Glyceria spicata, which could be locally abundant. Based on the diagnostic features discussed above, we identified a Glyceria-type pollen morphology that was recorded in small proportions in all the analysed surface spectra, making it difficult to perceive the local presence of the plant. This widespread pollen signal could be attributed to the generally anemophilous (while sometimes ambophilous; Schulze-Albuquerque et al., 2020) pollination of Poaceae species. However, the complete pollen diagrams of BAR, MF1b and MF3 (Figs. 5 to 7) unambiguously reveal the long-term presence of this species at MF3 (continuous curve; average $4.1 \pm 1.1 \%$ ) and its long-term absence or rarity at BAR (discontinuous curve of Cerealia-type; average $0.6 \pm 0.3 \%$ ) and MF1b (discontinuous curve; average $0.6 \pm 0.1 \%$ ). Furthermore, ponds and lakes could be distinguished on the basis of the pollen record of characteristic plants, such as components of Isoetion (Cicendia-Exaculum, 
Gratiola-type, Isoetes, Lythrum, Ranunculus-type) in ponds, and perennial hydrophytes (Potamogeton-type, Sparganium/Typha) in lakes.

\subsection{Initiation of peat-forming wetlands in the Rif}

The palaeoecological data available in the Rif provide some clues that can be used to reconstruct the past origin of the present-day peat-forming wetlands. The Bartete sequence (Reille, 1977) (Fig. 7) proves that sediment-accumulating wetlands have existed in the Rif for at least 13,000 years. Although few radiocarbon-based chronologies are available for this mountain range, those that do exist (Reille, 1977; Cheddadi et al., 2015, 2016; Muller et al., 2015) (Table 5) show unambiguously that sediment accumulation began at different periods from the end of the Lateglacial to the late Holocene. Among the investigated lakes (DAY1, DAY2, TAN) or ponds (BOU, MAR, MF3, MF4, TAY1), only MF4 harbours a significant community of peatland plant species (including Aulacomnium palustre, Carex distans, Danthonia decumbens, Eleocharis multicaulis, Lythrum junceum, Potentilla erecta, Polytrichum strictum, Sphagnum auriculatum). This suggests a possible evolution towards peat-forming communities, through the so-called terrestrialization process that is common in Boreal countries (Korhola, 1995; Muller et al., 2003). On the opposite, the contrasted SAR between open water bodies and peat-forming wetlands linked with the roughly constant agedepth models of the studied sites (Fig. 4) suggest that the MF1 fen did not initiate by terrestrialization from a pre-existing pond. This is supported by the presence of sand and significant pollen degradation at the base of the core MF1b, features consistent with the fen spread from a stream flowing down a gentle slope, i.e. through paludification process (Lavoie et al., 2005). It is likely that the sand deposited in the lower portion of the sequences of BAR, MF3 and BOU/BEK (Cheddadi et al., 2016) reveals similar origins for the concerned wetlands. Such initiations by paludification agree with the present-day ecology of Sphagnum auriculatum in North Africa, where it constitutes loose carpets on waterlogged soils below springs or along streams, mainly in forest environments (Muller et al., 2010, 2011). Only two peat-forming wetlands of the Jebala Range could have originated through terrestrialization: the wet meadow of MAR and the degraded swamp RHE1 (Reille, 1977) (Table 1) have indeed formed from ponds, recorded in the basal pollen spectra by Myriophyllum, associated at RHE1 with Ludwigia, Lythrum, Potamogeton and Glyceria-type. Initially interpreted as cereals by Reille (1977), the last taxon presents, in the lowest part of the RHE1 sequence, a peak clearly linked to hydrophytic taxa, revealing its aquatic nature. This could explain the abnormally high SAR of this peat-forming wetland $\left(1.13 \mathrm{~mm} \cdot \mathrm{yr}^{-1}\right)$.

The plant communities that developed at the onset of wetlands varied between the sites that developed from slow-running waters, possibly along previous river beds. Some of them, such as MF3 and BAR, were initially covered by alder swamps, although others, such as MF1, were open and dominated by herbaceous communities evocating the Sphagnum pond MF4.

\subsection{Controls of the past dynamics of peat-forming wetlands in the Rif}

Sometime after the initial phase of sand deposition in slow-moving waters (ca. 13,0005000 cal. BP at BAR; ca. 9100-8000 cal. BP at BOU/BEK; 5100-3500 cal. BP at MF1b; 5400-2400 cal. BP at MF3), these four sites evolved towards peaty clay-accumulating wetlands (around 2500-2000 cal. BP at BAR, $6700 \mathrm{cal}$. BP at BOU/BEK, $930 \mathrm{cal}$. BP at 
MF1b and $850 \mathrm{cal}$. BP at MF3). BAR and MF3, located on two different reliefs, were covered by alder swamps that were probably similar to the relictual MF5 that remains home to a rich peat-forming community including Alnus glutinosa, Frangula alnus, Ilex aquifolium, Prunus lusitanica and Salix atrocinerea. However, the MF3 sequence (Fig. 6) reveals that while the composition of the swamp undergrowth remained relatively unchanged for at least 5300 years, the respective abundance of each taxon has varied over time, at least at the edge of the pond: Ilex dominates the first half of the swamp's history until ca. $2500 \mathrm{cal}$. BP, at which point Frangula replaced it for about 4 centuries, and finally Salix spread, perhaps as a result of the contemporary opening of the alder grove. Approximately 900 cal. BP, the alder swamp closed again, which may have led to the regression of willow that regressed in its turn again a few centuries later.

The related sediment composition and wetland vegetation dynamics are controlled by autogenic (hydroseral plant succession) and allogenic factors (watershed forest cover, rainfall regime) (Payette, 1988; Korhola, 1996; Muller, 2001). Past changes affecting the nature of the sediment and/or hydrophytic plant communities should therefore reveal changes of one or more of these factors. With the sole exception of RHE1 (Reille, 1977), no local hydrophytic vegetation changes recorded in the Rif Mountains (Reille, 1977; Muller et al., 2015; Cheddadi et al., 2016; Abel-Schaad et al., 2018) (Figs. 5 to 7) are compatible with the hydroseral succession model initially described by Weber (1908) and Clements (1916). The climatic boundary conditions for peatland development, which induced high decomposition rates barely compensated for by production rates, may explain why the hydroseral succession is so poorly expressed in Northern Morocco. In contrast with the constancy of local hydrophytic plant communities, the regional forest cover underwent one major change, namely the lateHolocene decline of Cedrus (Reille, 1977; Muller et al., 2015; Cheddadi et al., 2016, 2017; Abel-Schaad et al., 2018). Available pollen sequences record this event at different periods: 4000-3000 cal. BP at BAR, 2900-2600 cal. BP at MF3, 2300-2000 cal. BP at MF1b, and 1500-800 cal. BP at BOU/BEK (Figs. 5 to 7) (Cheddadi et al., 2016, 2017; Abel-Schaad et al., 2018). While Cheddadi et al. (2017) attribute this decline to the late-Holocene climate aridification, its non-contemporaneity rather suggests the influence of human activities. On Jbel Bou Hachem, the first significant structural changes affecting peat-forming wetlands occurred soon after the cedar decline (Figs. 5 and 6), which probably reflects changes in the hydrology of watersheds induced by the regression of the tree cover. A similar hydrological change is reported on Jbel Tizirene by Cheddadi et al. (2015), who link the reduction in tree cover to enhanced soil erosion.

These results indirectly highlight human activities in the Rif since $3000 \mathrm{cal}$. BP, as cedar forest clearing impacted the hydrology of watersheds and sediment accumulation in wetlands. However, as previously noted (Cheddadi et al., 2015; Muller et al., 2015), and unlike contemporary pollen records in Europe, the pollen data from the Jebala Range show no clear evidence of past agriculture. It appears notably that although cereal cultivation was reported for more than 7,000 years on the coast of Northern Rif (Ballouche and Marinval, 2003; Zielhofer and Linstädter, 2006; Zapata et al., 2013), the cereal-type pollen signal recorded in the central Rif by Reille (1977) and Muller et al. (2015) is clearly related to the open-water nature of the wetlands and can be assigned to Glyceria-type pollen, mainly produced by in-situ floating populations of Glyceria spicata. Consequently, the changes that 
affected the mountain forests of Rif before the end of the Middle Ages (Reille, 1977; Cheddadi et al., 2015, 2016, 2017; Muller et al., 2015) may be primarily attributed to animal husbandry. This is supported by the contemporary increases of Plantago in the BAR sequence (Reille, 1977) (Fig. 7) and of coprophilous fungi in the BEK one (Abel-Schaad et al., 2018), which indicate the local occurrence of grazing. Such differences in human activities could explain the delay of the anthropogenic impact on landscapes between coastal and mountain areas (Cheddadi et al., 2018): while cereal cultivation seems to have triggered the early Holocene decline of forest ecosystems on the coast (Zapata et al., 2013), animal husbandry should have prevailed for millennia in the Jebala Range, with a moderate and later impact on vegetation cover.

\section{Conclusion}

First, our results highlight that the consideration of the pollen record of hydrophytic plant communities clearly improve the interpretation of pollen spectra. Some hydrophytic taxa have indeed been misinterpreted as anthropogenic indicators in previous studies conducted in the Rif (e.g., Cerealia-type, Galium-type, Potentilla and Ranunculaceae; Reille, 1977; Cheddadi et al., 2018), leading to overestimating the past role of human populations. In particular, our study showed that it is difficult to distinguish between the pollen of cereals and that of certain wild Poaceae species including Glyceria spp., and that such confusion could lead to possible misinterpretations, as in Andrieu-Ponel et al. (2021) at Lake Acigöl in Turkey. Another ecological misinterpretation was reported for the Erica-type pollen record that is generally interpreted in North Africa as revealing regional evergreen shrublands (Reille, 1977; Benslama et al., 2010; Cheddadi et al., 2018), while it can come from local hydrophytic populations of Erica ciliaris (Northern Morocco) or E. scoparia (Northern Tunisia and Northeastern Algeria (Ghit et al., 2018)).

Second, our work provides a historical perspective for the conservation of the invaluable and highly threatened "peatlands" of Northern Morocco. It notably reveals the ancient wooded status of some of them, which were dominated by complex tree communities (including Alnus glutinosa, Frangula alnus, Ilex aquifolium, Laurus nobilis and Prunus lusitanica) and surrounded by deciduous oak forests before recent anthropogenic clearing. Previous studies show that the situation is similarly worrying at the scale of Maghreb. The rapid demographic increase in the three countries of the Maghreb and the difficult economic context in remote and landlocked regions (such as mountainous areas) have led in the past decades to severe degradation and destruction of most of the North African peatlands. That some of these benefit from a protected status has been clearly inadequate for guaranteeing their durability: the Tunisian Dar Fatma peatland reserve, for example, was damaged and over-pastured after the 2011 revolution; the alder swamps of the Algerian El Kala National Park are disappearing progressively because of illegal cutting and draining (De Bélair and Samraoui, 1994; Belouahem-Abed et al., 2011); and the Northern Moroccan peatlands of Jbel Bou Hachem were severely damaged by overgrazing and forest clearing and burning (Muller et al., 2015). In the coming decades, climate change will constitute an additional constraint for these habitats already greatly weakened by human activity. Based on the historical background, protection policies that guarantee their long-term survival must be urgently 
implemented given their inestimable historical and patrimonial value as well as their biological and ecological richness.

\section{Acknowledgements}

We thank S. Canal for loss-on-ignition measurements, S. Rouland for help with pollen measurements, C. Favier for help with statistics, G. Escarguel, V. Lebreton and an anonymous reviewer for their helpful comments, and D. Glassman (Washington, DC, USA) for editorial assistance. The work was supported by the Egide-CMIFM program (PHC Volubilis MA/07/172) and the project Medyna (FP7-PEOPLE-2013-IRSES). This publication is the contribution ISEM n ${ }^{\circ} 2021-217$ SUD.

\section{References}

Abel-Schaad, D., Iriarte, E., López-Sáez, J.A., Pérez-Díaz, S., Sabariego Ruiz, S., Cheddadi, R., Alba-Sánchez, F., 2018. Are Cedrus atlantica forests in the Rif Mountains of Morocco heading towards local extinction? The Holocene 28, 1023-1037.

Ajbilou, R., Marañón, T., Arroyo, J., 2006. Ecological and biogeographical analyses of Mediterranean forests of northern Morocco. Acta Oecologica 29, 104-113.

Amami, B., Muller, S.D., Rhazi, L., Grillas, P., Rhazi, M., Bouahim, S., 2010. Modern pollen-vegetation relationships within a small Mediterranean temporary pool (western Morocco). Review of Palaeobotany and Palynology 162, 213-225.

Andersen, R., Farrell, C., Graf, M., Muller, F., Calvar, E., Frankard, P., Caporn, S., Anderson, P., 2016. An overview of the progress and challenges of peatland restoration in Western Europe. Restoration Ecology 25, 271-282.

Andersen, S.T., 1979. Identification of wild grass and cereal pollen. Danmarks Geologiske Undersøgelse Arbog, 69-92.

Andrieu- Ponel, V., Rochette, P., Demory, F., Alçiçek, H., Boulbes, N., Bourlès, D., Helvac1, C., Lebatard, A.E., Mayda, S., Michaud, H., Moigne, A.-M., Nomade, S., Perrin, M., Ponel, P., Rambeau, C., Vialet, A., Gambin, B., Cihat Alçiçek, M., 2021. Continuous presence of proto-cereals in Anatolia since $2.3 \mathrm{Ma}$, and their possible co- evolution with large herbivores and hominins. Scientific Reports 11, 8914.

Ballouche, A., Marinval, P., 2003. Données palynologiques et carpologiques sur la domestication des plantes et l'agriculture dans le Néolithique ancien du Maroc septentrional (site de Kaf Taht El-Ghar). Revue d'Archéométrie 27, 49-54.

Belouahem-Abed, D., Belouahem, F., Benslama, M., de Bélair, G., Muller, S.D., 2011. Les aulnaies de Numidie (N.E. algérien) : biodiversité floristique, vulnérabilité et conservation. Comptes Rendus Biologies 334, 61-73.

Beug, H.-J., 1961. Leitfaden der Pollenbestimmung für Mitteleuropea und angrenzende Gebiete. Fischer, Stuttgart.

Beug, H.-J., 2004. Leitfaden der Pollenbestimmung für Mitteleuropea und angrenzende Gebiete. Pfeil, München.

Benabid, A., 2000. Flore et écosystèmes du Maroc : évaluation et préservation de la biodiversité. Ibis Press, Paris.

Benslama, M., Andrieu-Ponel, V., Guiter, F., Reille, M., de Beaulieu, J.-L., Migliore, J., Djamali, M., 2010. Nouvelles contributions à l'histoire tardiglaciaire et holocène de la végétation en Algérie : analyses polliniques de deux profils sédimentaires du complexe humide d'El-Kala. Comptes Rendus Biologies 333, 744-754.

Ben Tiba, B., Reille, M., 1982. Recherches pollenanalytiques dans les montagnes de Kroumirie (Tunisie septentrionale) : premiers résultats. Ecologia Mediterranea 8, 75-86.

Berglund, B.E., Ralska-Jasiewiczowa, M., 1986. Pollen analysis and pollen diagrams. In Berglund B.E. (Ed.), Handbook of Holocene palaeoecology and palaeohydrology. Wiley and sons, Chichester, pp. 455-484.

Birks, H.J.B., Birks, H.H., 1980. Quaternary Palaeoecology. Arnold, London. 
Bragg, O., Lindsay, R. (Eds.), 2003. Strategy and Action Plan for Mire and Peatland Conservation in Central Europe. Wetlands International, Wageningen.

Brown, L.D., Cai, T.T., DasGupta, A., 2001. Interval Estimation for a Binomial Proportion. Statistical Science $16,101-133$.

Brun, C., Dessaint, F., Richard, H., Bretagnolle, F., 2007. Arable-weed flora and its pollen representation: A case study from the eastern part of France. Review of Palaeobotany and Palynology 146, 29-50.

Bunting, M.J., 2003. Pollen-based reconstruction of cultural landscapes: an investigation of pollen source area for non-arboreal taxa. Review of Palaeobotany and Palynology 125, 285-298.

Chalouan, A., Michard, A., El Kadiri, K., Negro, F., Frizon de Lamotte, D., Soto, J.I., Saddiqi, O., 2008. The Rif Belt. In: Michard, A., Saddiqi, O., Chalouan, A., Frizon de Lamotte D. (Eds.), Continental Evolution: The Geology of Morocco. Structure, Stratigraphy, and Tectonics of the Africa-Atlantic-Mediterranean Triple Junction. Springer-Verlag, Berlin, Heildelberg, pp. 203-302.

Cheddadi, R., Nourelbait, M., Bouaissa, O., Tabel, J., Rhoujjati, A., López-Sáez, J.A., Alba-Sánchez, F., Khater, C., Ballouche, A., Dezileau, L., Lamb, H., 2015. A history of Human impact on Moroccan mountain landscapes. African Archaeological Reviews 32, 233-248.

Cheddadi, R., Bouaissa, O., Rhoujjati, A., Dezileau, L., 2016. Environmental changes in the Moroccan western Rif Mountains over the last 9,000 years. Quaternaire, 27: 15-25.

Cheddadi, R., Henrot, A.-J., François, L., Boyer, F., Bush, M., Carré, M., Coissac, E., De Oliveira, P.O., Ficetola, F., Hambuckers, A., Huang, K., Lézine, A.-M., Nourelbait, M., Rhoujjati, A., Taberlet, P., Sarmiento, F., Abel-Schaad, D., Alba-Sánchez, F., Zheng, Z., 2017. Microrefugia, climate change, and conservation of Cedrus atlantica in the Rif Mountains, Morocco. Frontiers in Ecology and Evolution 5, 114.

Cheddadi, R., Palmisano, A., López-Sáez, J.A., Nourelbait, M., Zielhofer, C., Tabel, J., Rhoujjati, A., Khater, C., Woodbridge, J., Lucarini, G., Broodbank, C., Fletcher, W.J., Roberts, N., 2018. Human demography changes in Morocco and environmental imprint during the Holocene. The Holocene 29, 816-829.

Clements, F.E., 1916. Plant succession, an analysis of the development of vegetation. Publication 242. Carnegie Institute, Washington.

Dahlgren, R., Lassen, P., 1972. Studies in the Flora of Northern Morocco. I. Some poor fen communities and notes on a number of northern and Atlantic plant species. Botaniska Notiser 125, 439-464.

Damblon, F., 1991. Contribution pollenanalytique à l'histoire des forêts de chêne liège au Maroc : La subéraie de Krimda. Palaeoecology of Africa 22, 171-183.

Davis, O.K., 1984. Pollen frequencies reflect vegetation patterns in a Great Basin (U.S.A.) mountain range. Review of Palaeobotany and Palynology 40, 295-315.

De Bélair, G., Samraoui, B., 1994. Death of a lake: Lac Noir in the Northeastern Algeria. Environmental Conservation 21, 169-172.

Dobignard, A., Chatelain, C., 2010-2013. Index synonymique de la flore d'Afrique du Nord, 2 vol. Conservatoire et jardin botaniques, Genève.

Erdtman, G., 1943. An introduction to pollen analysis. Chronica Botanica Cie, Waltham.

Faegri, K., Iversen, J., 1989. Textbook of pollen analysis, 4th edition. Wiley and sons, Chichester.

Fennane, M, Ibn Tattou, M, Mathez, J, Ouyahya, A, El Oualidi, J., 1999. Flore pratique du Maroc. Manuel de détermination des plantes vasculaires, vol. 1. Travaux de l'Institut Scientifique, Sér. Bot. 36, Rabat.

Fennane, M, Ibn Tattou, M, Ouyahya, A, El Oualidi, J., 2007. Flore pratique du Maroc. Manuel de détermination des plantes vasculaires, vol. 2. Travaux de l'Institut Scientifique, Sér. Bot. 38, Rabat.

Fennane, M., Ibn Tattou, M., El Oualidi, J., 2014. Flore pratique du Maroc. Manuel de détermination des plantes vasculaires, vol.3. Travaux de l'Institut Scientifique, Sér. Bot. 40, Rabat.

Ferchichi-Ben Jamaa, H., Muller, S.D., Daoud-Bouattour, A., Ghrabi-Gammar, Z., Rhazi, L., Soulié-Märsche, I., Ouali, M., Ben Saad-Limam, S., 2010. Structures de végétation et conservation des zones humides temporaires méditerranéennes : la région des Mogods (Tunisie septentrionale). Comptes Rendus Biologies 333, 265-679.

Firbas, F., 1937. Der pollenanalytische Nachweis des Getreidebaus. Zeitschrift für Botanik 31, 447-478.

Ghit, K., Muller, S.D., de Bélair, G., Belouahem-Abed, D., Daoud-Bouattour, A., Benslama, M., 2018. Palaeoecological significance and conservation of peat-forming wetlands of Algeria. Revue d'Ecologie 34, 414-430. 
Grimm, E.C., 1987. CONISS: a FORTRAN 77 program for stratigraphically constrained cluster analysis by the method of incremental sum of squares. Computers and Geosciences 13, 13-35.

Grohne, U., 1957. Die Bedeutung des Phasenkrontrastsverfahrens für die Pollenanalyse, dargelegt am Beispiel der Gramineenpollen vom Getreidetyp. Photographie und Forschung 7, 237-248.

Hammer, Ø., Harper, D.A.T., Ryan, P.D., 2001. PAST: Paleontological Statistics software package for education and data analysis. Paleontologia Electronica 4, 1-9.

Heiri, O., Lotter, A.F., Lemcke, G., 2001. Loss on ignition as a method for estimating organic and carbonate content in sediments: reproducibility and comparability of results. Journal of Paleolimnology 25, 101110.

Hjelle, K.L., 1997. Relationships between pollen and plants in human-influenced vegetation types using presence-absence data in western Norway. Review of Palaeobotany and Palynology 99, 1-16.

Joly, C., Barillé, L., Barreau, M., Mancheron, A., Visset, L., 2007. Grain and annulus diameter as criteria for distinguishing pollen grains of cereals from wild grasses. Review of Palaeobotany and Palynology 146, 221-233.

Joosten, H., Tanneberger, F., Moen, A. (Eds.), 2017. Mires and Peatlands of Europe: Status, Distribution and Conservation. Schweizerbart Science Publishers, Stuttgart.

Juggins, S., 2020. rioja: Analysis of Quaternary Science Data. R package version 0.9-26, https://cran.rproject.org/package $=$ rioja.

Korhola, A., 1995. Lake terrestrialization as a mode of mire formation: a regional review Publications of the National Board of Waters and the Environment A 207, 11-21.

Korhola, A., 1996. Initiation of a sloping mire complex in southwestern Finland: Autogenic versus allogenic controls. Ecoscience 3, 216-222.

Küster, H., 1988. Vom warden einer kulturlandschaft: vegetationsgeschichtliche studien amauerberg (Südbayern). Acta Humaniora, Weinheim.

Lavoie, M., Paré, D., Fenton, N., Groot, A., Taylor, K., 2005. Paludification and management of forested peatlands in Canada: a literature review. Environmental Reviews 13, 21-50.

Le Floc'h, E., Boulos, L., Véla, E., 2010. Flore de Tunisie, Catalogue synonymique commenté. Banque Nationale de Gènes, Ministère de l'Environnement et du Développement Durable, Tunis.

Mazier, F., Galop, D., Brun, C., Buttler, A., 2006. Modern pollen assemblages from grazed vegetation in the western Pyrenees, France: a numerical tool for more precise reconstruction of past cultural landscapes. The Holocene 16, 91-103.

Médail, F., Quézel, P., 1999. Biodiversity hotspots in the Mediterranean Basin: setting global conservation priorities. Conservation Biology 13, 1510-1513.

Meddour, R., Laribi, M., 1999. La ripisylve à Alnus glutinosa (L.) Gaertn. de l'Akfadou (Grande-Kabylie, Algérie). Documents phytosociologiques 19, 385-400.

Muller, S.D., 2001. Conditions de l'accumulation du carbone dans une tourbière du Québec méridional : l'influence des facteurs autogènes et des contrôles allogènes. PhD thesis, Université Aix-Marseille-3, France and Université de Montréal, Canada.

Muller, S.D., Richard, P.J.H., Larouche, A.C., 2003. Holocene development of a peatland (southern Québec): a spatio-temporal reconstruction based on pachymetry, sedimentology, microfossils and macrofossils. The Holocene 13, 649-664.

Muller, S.D., Daoud-Bouattour, A., Belouahem-Abed, D., Ben Haj Jilani, I., Ben Saad-Limam, S., Benslama, M., Ferchichi-Ben Jamaa, H., Rhazi, L., Ghrabi-Gammar, Z., 2010. Peat mosses (Sphagnum) and related plant communities of North Africa. I. The Numidian-Kroumirian range (Algeria-Tunisia). Flora Mediterranea 20, 159-178.

Muller, S.D., Rhazi, L., Saber, E.-R., Rifai, N., Daoud-Bouattour, A., Bottollier-Curtet, M., Ben Saad-Limam, S., Ghrabi-Gammar, Z., 2011. Peat mosses (Sphagnum) and related plant communities of North Africa. II. The Tingitanean-Rifan range (northern Morocco). Nova Hedwigia 93: 335-352.

Muller, S.D., Rhazi, L., Andrieux, B., Bottollier-Curtet, M., Fauquette, S., Saber, E.-R., Rifai, N., DaoudBouattour, A., 2015. Vegetation history of the Western Rif Mountains (NW Morocco): origin, lateHolocene dynamics and human impact. Vegetation History and Archaeobotany 24, 487-501.

Odgaard, B.V., 1999. Fossil pollen as a record of past biodiversity. Journal of Biogeography 26, 7-17. 
Payette, S., 1988. Late-Holocene development of subarctic ombrotrophic peatlands: allogenic and autogenic succession. Ecology 69, 516-531.

Quézel P., Barbero M., 1990. Les forêts méditerranéennes. Problèmes posés par leur signification historique, écologique et leur conservation. Acta Botanica Malacitana 15, 145-178.

Reille, M., 1977. Contribution pollenanalytique à l'histoire holocène de la végétation des montagnes du Rif (Maroc septentrional). Bulletin AFEQ-INQUA suppl. 50, 53-76.

Reimer, P.J., Austin, W.E.N., Bard, E., Bayliss, A., Blackwell, P.G., Bronk Ramsey, C., Butzin, M., Cheng, H., Edwards, R.L., Friedrich, M., Grootes, P.M., Guilderson, T.P., Hajdas, I., Heaton, T.J., Hogg, A.G., Hughen, K.A., Kromer, B., Manning, S.W., Muscheler, R., Palmer, J.G., Pearson, C., van der Plicht, J., Reimer, R.W., Richards, D.A., Scott, E.M., Southon, J.R., Turney, C.S.M., Wacker, L., Adolphi, F., Büntgen, U., Capano, M., Fahrni, S.M., Fogtmann-Schulz, A., Friedrich, R., Köhler, P., Kudsk, S., Miyake, F., Olsen, J., Reinig, F., Sakamoto, M., Sookdeo, A., Talamo, S., 2020. The IntCal20 Northern Hemisphere radiocarbon age calibration curve (0-55 cal kBP). Radiocarbon 62, 725.

Romagny, A., Münch, P., Cornée, J.-J., Corsini, M., Azdimousa, A., Melinte-Dobrinescu, M.C., Drinia, H., Bonno, M., Arnaud, N., Monié, P., Quillévéré, F., Ben Moussa, A., 2014. Late Miocene to present-day exhumation and uplift of the Internal Zone of the Rif chain: Insights from low temperature thermochronometry and basin analysis. Journal of Geodynamics 77, 39-55.

Salamani, M., 1991. Premières données palynologiques sur l'histoire Holocène du massif de l'Akfadou (GrandeKabylie, Algérie). Ecologia Mediterranea 17, 145-159.

Salamani, M., 1993. Premières données paléophytogéographiques du cèdre de l'Atlas (Cedrus atlantica) dans la région de grande Kabylie (NE Algérie). Palynosciences 2, 147-155.

Sauvage, C., 1958. Intérêt biogéographique du Bou-Hachem (Rif occidental). Bulletin de la Société des Sciences Naturelles et Physiques du Maroc 38, 17-26.

Schulze-Albuquerque, I., Galindo Da Costa, A.C., Milet-Pinheiro, P., Do Amaral Ferraz Navarro, D.M., Thomas W.W., Machado, I.C., 2020. Visual and olfactory floral cues related to ambophilous pollination systems in Poaceae. Botanical Journal of the Linnean Society 192, 242-257.

Stambouli-Essassi, S., Roche, E., Bouzid, S., 2007. Evolution de la végétation et du climat dans le Nord-Ouest de la Tunisie au cours des 40 derniers millénaires. Geo-Eco-Trop 31, 171-214.

Stuiver, M., Reimer, P.J., 1993. Extended ${ }^{14} \mathrm{C}$ database and revised CALIB radiocarbon calibration program. Radiocarbon 35, 215-230.

Suchéras-Marx, B., Escarguel, G., Ferreira, J., Hammer, Ø, 2019. Statistical confidence intervals for relative abundances and abundance-based ratios : Simple practical solutions for an old overlooked question. Marine Micropaleontology 151, 101751.

Taiqui, L., 1997. La dégradation écologique au Rif marocain : nécessités d’une nouvelle approche. Mediterránea, Serie de estudios biológicos 16, 5-17.

Taleb, M.S., Fennane, M., 2011. Zones Importantes pour les Plantes au Maroc. In: Radford, E.A., Catullo, G., de Montmollin, B. (Dirs.), Zones Importantes pour les Plantes en Méditerranée méridionale et orientale : Sites prioritaires pour la conservation. IUCN, Gland and Málaga, pp. 29-32.

Tauber, H., 1965. Differential pollen dispersion and the interpretation of pollen diagrams. Danmarks Geologiske Undersøgelse, Raekke 2 (89), 69.

Tweddle, J.C., Edwards, K.J., Fieller, N.R.J., 2005. Multivariate statistical and other approaches for the separation of cereal from wild Poaceae pollen using a large Holocene dataset. Vegetation History and Archaeobotany 14, 15-30.

Véla, E., Benhouhou, S., 2007. Evaluation d'un nouveau point chaud de biodiversité végétale dans le Bassin méditerranéen (Afrique du Nord). Comptes Rendus Biologies 33, 589-605.

Weber, C.A., 1908. Aufbau und Vegetation der Moore Norddeutschlands. Engler's Botanische Jahrbuch 40 (suppl.), 19-34.

Zapata, L., López-Sáez, J.A., Ruiz-Alonso, M., Linstädter, J., Pérez-Jordà, G., Morales, J., Kehl, M., PeñaChocarro, L., 2013. Holocene environmental change and human impact in NE Morocco: Palaeobotanical evidence from Ifri Oudadane. The Holocene 23, 1286-1296.

Zielhofer, C., Linstädter, J., 2006. Short-term mid-Holocene climatic deterioration in the West Mediterranean region: climatic impact on Neolithic settlement pattern?. Zeitschrift für Geomorphology N.F. Suppl. 142, $1-17$. 


\section{Table and Figures}

\begin{tabular}{|c|c|c|c|c|c|c|c|c|}
\hline \multirow{3}{*}{$\begin{array}{l}\text { Jbel } \\
\text { Bou Hachem }\end{array}$} & \multirow{3}{*}{$\begin{array}{l}\text { Site } \\
\text { Maison Forestière-1 }\end{array}$} & \multirow{3}{*}{$\begin{array}{l}\text { Code } \\
\text { MF1 }\end{array}$} & \multirow{3}{*}{$\begin{array}{l}\text { Nature } \\
\text { Fen }\end{array}$} & \multirow{2}{*}{\multicolumn{2}{|c|}{$\begin{array}{l}\text { Altitude Latitude } \\
\text { (m a.s.l.)N }\end{array}$}} & \multirow{2}{*}{\multicolumn{3}{|c|}{$\begin{array}{l}\text { LongitudePhytosociologicalFloristicMean SAR } \\
\text { W }\end{array}$}} \\
\hline & & & & & & & & \\
\hline & & & & 1064 & $35^{\circ} 15^{\prime} 12^{\prime}$ & $" 05^{\circ} 25 ' 14 " 20.05 .2010$ & 32 & 0.26 \\
\hline & Maison Forestière-2 & MF2 & Fen & 1092 & $35^{\circ} 15^{\prime} 22^{\prime}$ & $" 05^{\circ} 25^{\prime} 40^{\prime \prime} 20.05 .2010$ & 26 & \\
\hline & Maison Forestière-3 & MF3 & Swamp/pond & 1096 & $35^{\circ} 15^{\prime} 32^{\prime \prime}$ & $" 05^{\circ} 25$ '54" 13.06.2012 & 52 & 1.01 \\
\hline & Maison Forestière-4 & MF4 & Sphagnum pond & 1213 & $35^{\circ} 15^{\prime} 13^{\prime}$ & $" 05^{\circ} 25^{\prime} 58^{\prime \prime} 16.06 .2012$ & 40 & \\
\hline & Maison Forestière-5 & MF5 & Swamp & 1300 & $35^{\circ} 15^{\prime} 04^{\prime}$ & "05²6’21" 21.10.2014 & 25 & \\
\hline & Tayenza-1 & TAY1 & 1 Temporary pond & 980 & $35^{\circ} 16^{\prime} 11^{\prime}$ & $" 05^{\circ} 26^{\prime} 09 " 23.10 .2014$ & 26 & \\
\hline \multirow[t]{5}{*}{ Sougna } & Bartete & BAR & Fen & 1249 & $35^{\circ} 01^{\prime} 51^{\prime}$ & $" 05^{\circ} 14{ }^{\prime} 59 " 14.06 .2012$ & 37 & 0.19 \\
\hline & Bazoukout & BAZ & Fen & 1143 & $35^{\circ} 02^{\prime} 10^{\prime \prime}$ & "05¹4'38" 14.06.2012 & 30 & \\
\hline & Marzine & MAR & Pond/wet meadow & 720 & $35^{\circ} 06^{\prime} 02^{\prime}$ & $" 05^{\circ} 20^{\prime} 09 " 21.05 .2010$ & 37 & 0.88 \\
\hline & Tanakob Lake & TAN & Acid lake & 840 & $35^{\circ} 07^{\prime} 42^{\prime}$ & $" 05^{\circ} 26^{\prime} 31^{\prime \prime}$ & & 1.17 \\
\hline & Tanakob Fen & TANT & TFen & 791 & $35^{\circ} 07^{\prime} 21^{\prime}$ & $" 05^{\circ} 26^{\prime} 20^{\prime \prime} 20.05 .2010$ & 22 & \\
\hline \multirow[t]{3}{*}{ Khezana } & Al-Bayda Fen & $\mathrm{ABF}$ & Fen & 1125 & $35^{\circ} 01^{\prime} 46^{\prime}$ & $" 05^{\circ} 12^{\prime} 33^{\prime \prime} 22.05 .2010$ & 27 & \\
\hline & Boujdayem & BOU & Temporary pond & 1202 & $35^{\circ} 01^{\prime} 22^{\prime}$ & "05¹2’24" 21.05.2010 & 39 & 0.93 \\
\hline & Rhesana-1 & RHE1 & 1 Swamp & 1300 & n.a. & n.a. & & 1.01 \\
\hline \multirow[t]{2}{*}{ Tizirène } & Dayla-1 & DAY 1 & 1 Alkaline lake & 1393 & $35^{\circ} 01^{\prime} 09^{\prime}$ & $" 05^{\circ} 00^{\prime} 02 "$ & & \\
\hline & Dayla-2/Aanasser & DAY2 & 2Alkaline lake & 1300 & $35^{\circ} 01^{\prime} 02^{\prime \prime}$ & "0459'30" 22.05.2010 & 33 & 5.59 \\
\hline
\end{tabular}

Table 1. Sites studied in the Rif. Certain sites were previously studied and sometimes differently named: BAR, Daya Arbatète (Reille 1977); BOU, Bab el Karn (Cheddadi et al., 2016; Abel-Schaad et al., 2018); DAY1, Mare à Cypéracées, jbel Tizirène (Reille 1977); DAY2, Etang près d'el Anasser, jbel Tizirène (Reille 1977) and Aanasser (Cheddadi et al., 2015); MF1 (Muller et al., 2015); MF3, Mare à sphaignes du jbel Bou Hachem (Reille 1977); RHE1, Tourbière à sphaignes entre Bab Taza et Fifi (Reille 1977); TAN and TANT (Reille 1977). SAR: sediment accumulation rate; n.a.: not available. 


\begin{tabular}{|c|c|c|c|c|c|c|c|c|c|c|c|c|c|}
\hline & $\mathrm{ABF}$ & BAR & BAZ & $\mathrm{BOU}$ & DAY2 & MAR & MF1 & MF2 & MF3 & MF4 & MF5 & TANT & TAY1 \\
\hline Date & 22.05 .2010 & 14.06 .2012 & 14.06 .2012 & 21.05 .2010 & 22.05 .2010 & 21.05 .2010 & 20.05 .2010 & 20.05 .2010 & 13.06 .2012 & 16.06 .2012 & 21.10 .2014 & 23.10 .2014 & 20.05 .2010 \\
\hline Water depth $(\mathrm{cm})$ & 0 & 0 & 5 & 50 & 150 & 150 & 0 & 0 & 0 & 80 & 0 & 0 & 20 \\
\hline Species richness & 27 & 37 & 30 & 39 & 33 & 37 & 32 & 26 & 52 & 40 & 25 & 22 & 26 \\
\hline Wetland surface (ha) & 0.03 & 0.7 & 0.1 & 0.4 & 6.6 & 0.7 & 0.12 & 0.18 & 0.8 & 0.07 & 0.5 & 0.2 & 0.15 \\
\hline $\begin{array}{l}\text { Charophytes and Bryophytes } \\
\text { Aulacomnium palustre (Hedw.) }\end{array}$ & 2 & 1 & 1 & & & & 1 & & 1 & $1-2$ & & & \\
\hline $\begin{array}{l}\text { Schwaegr. } \\
\text { Chara globularis Thuillier } \\
\text { Nitella opaca C.Agardh }\end{array}$ & & & & 2 & 1 & & & & & & & & \\
\hline $\begin{array}{l}\text { Polytrichum commune Hedw. } \\
\text { Sphagnum auriculatum Schimp. }\end{array}$ & & + & 1 & & & & 4 & 2 & 2 & $\begin{array}{l}2-3 \\
4-5\end{array}$ & & 1 & $\begin{array}{c}1-2 \\
1\end{array}$ \\
\hline \multicolumn{14}{|c|}{ Tracheophytes (Lycopodiophytes, Polypodiophytes and Spermatophytes) } \\
\hline $\begin{array}{l}\text { Acis autumnalis (L.) Herb. } \\
\text { Acis longifolia J.Gay ex M.Roem. }\end{array}$ & & & & & & & & & + & & & + & \\
\hline $\begin{array}{l}\text { Agrostis capillaris L. subsp. } \\
\text { castellana (Bois. \& Reut.) } \\
\text { O.Bolos, Massales \& Vigo }\end{array}$ & & & & & & & & & & 2 & & & \\
\hline Agrostis stolonifera $\mathrm{L}$. & & & & & & & & & & & & + & \\
\hline Aira cupaniana Guss. & & & + & & & & & & & 1 & & & \\
\hline Alisma lanceolatum With. & & & & & $1-2$ & & & & & & & & \\
\hline Alnus glutinosa (L.) Gaertn. & & & & & & & & & 2 & & 4 & & \\
\hline Alopecurus aequalis Sobol. & & & & & + & & & & & & & & \\
\hline Anthemis praecox Link & & & & & & & & & & 1 & & & \\
\hline Anthoxanthum odoratum L. & & & & & & 1 & 4 & & 3 & & & & \\
\hline Athyrium filix-femina (L.) Roth. & & & & & & & & & & & 1 & & \\
\hline Baldellia ranunculoides (L.) Parl. & 1 & 2 & & & & & & & $2-3$ & 2 & & & \\
\hline $\begin{array}{l}\text { Baldellia repens (Lam.) van } \\
\text { Ooststr. ex Lawalrée }\end{array}$ & & & 2 & 2 & & 4 & 2 & $2-3$ & & & 1 & & $2-3$ \\
\hline Bellis sylvestris Cirillo & & & & 1 & & + & & & & & & & \\
\hline Blechnum spicant (L.) Roth & & & & & & & & & + & & $1-2$ & & \\
\hline Briza maxima $\mathrm{L}$. & & & & & & & & & + & & & & \\
\hline Briza minor L. & + & $1-2$ & 1 & & & + & + & & 1 & 1 & & & \\
\hline Bromus madritensis $\mathrm{L}$. & & & & & & & & & & 1 & & & \\
\hline Callitriche brutia Petagna & & & & $1-2$ & & & & & + & & & & 2 \\
\hline Callitriche stagnalis Scop. & & & + & & 2 & & & & 1 & & & & 1 \\
\hline Callitriche truncata Guss. & & & & & & & & & 1 & & & & \\
\hline Calluna vulgaris (L.) Hull & & & & & & & 1 & & & & & & \\
\hline $\begin{array}{l}\text { Carex cuprina (Sandor ex Heuff.) } \\
\text { Nendtv. ex A.Kern. }\end{array}$ & & & & & & 1 & & & & & & & \\
\hline Carex distans $\mathrm{L}$. & 2 & 5 & 2 & & & & $1-2$ & 2 & + & 1 & & & \\
\hline $\begin{array}{l}\text { Carex divulsa Stokes } \\
\text { Carex echinata Murray }\end{array}$ & & 1 & & & & + & 1 & 2 & & & & & \\
\hline Carex flacca Schreb. & & & & & & + & & & & & & & \\
\hline $\begin{array}{l}\text { Carex ovalis Good. } \\
\text { Carex pseudocyperus L. }\end{array}$ & 3 & 2 & & 1 & $1-2$ & & 1 & & 1 & & & & \\
\hline Carex remota $\mathrm{L}$. & & & & & & & & & & & 1 & & \\
\hline Carex serotina Mérat & & & & & & & & 3 & + & & & & \\
\hline
\end{tabular}


Chamaemelum fuscatum (Brot.) Vasc.

Cicendia filiformis (L.) Delarbre

Cistus creticus $\mathrm{L}$.

Cistus monspeliensis $\mathrm{L}$

Cistus salviifolius $\mathrm{L}$.

Crataegus monogyna Jacq.

Cuscuta epithymum L.

Cyperus longus $\mathrm{L}$.

Dactylorhiza maurusia (Emb. \&

$$
\text { Maire) Holub }
$$

Danthonia decumbens (L.) DC.

Dittrichia viscosa (L.) Greuter

Dorycnium rectum (L.) Ser.

Eleocharis multicaulis (Sm.)

$$
\text { Desv. }
$$

Eleocharis palustris (L.) Roem. \& Schult.

Erica arborea $\mathrm{L}$

Erica ciliaris L.

Erica umbellata $\mathrm{L}$.

Exaculum pusillum (Lam.) Caruel Frangula alnus Mill. subsp.

baetica (Willk. \& E.Rev.)

$$
\text { Rivas Goday ex Devesa }
$$

Galium palustre L.

Galium palustre L. subsp.

elongatum (C.Presl) Lange

Gaudinia fragilis (L.) P. Beauv.

Genista ancistrocarpa Maire

Glyceria spicata (Biv.) Guss.

Gratiola mauretanica

Hedera helix L. subsp. maroccana

Helosciadium inundatum (L.)

$$
\text { W.D.J.Koch }
$$

Helosciadium nodiflorum (L.)

$$
\begin{aligned}
& \text { W.D.J.Koch } \\
& \text { cus lanatus } \mathrm{L} \text {. }
\end{aligned}
$$

Hypericum humifusum $\mathrm{L}$.

Hypericum perfoliatum $\mathrm{L}$

Hypericum perfoliaum $\mathrm{L}$

Hypericum tetrapterum $\mathrm{F}$.

Hypericum tomentosum $\mathrm{L}$.
Ilex aquifolium $\mathrm{L}$.

lex aquifolium $\mathrm{L}$.

Illecebrum verticillatum $\mathrm{L}$

Isoetes histrix Bory

Isoetes velata $\mathrm{A}$.Braun

solepis cernua (Vahl.) Roemer \&

$$
\text { Schultes }
$$

Isolepis setacea $(\mathrm{L}$.$) R.Br.$ 
Juncus capitatus Weigel

Juncus conglomeratus $\mathrm{L}$.

Juncus foliosus Desf.

Juncus heterophyllus Dufour

Juncus pygmaeus L.C.M.Richard

Juncus tenageia L.fil.

Lemna minor $\mathrm{L}$.

Leontodon tuberosus $\mathrm{L}$.

Lobelia urens $\mathrm{L}$.

Lotus angustissimus L. subsp. hispidus (Desf. ex DC.)

Bonnier \& Layens

Lotus pedunculatus Cav.

Ludwigia palustris (L.)

Lycopus europaeus $\mathrm{L}$.

Andensis (L.) U.Mann

$$
\text { \& Anderb. }
$$

Lysimachia tenella $\mathrm{L}$.

Lysimachia tyrrhenia (Thore)

U.Manns \& Anderb.

Lythrum borysthenicum (Schrank)

$$
\text { Litv. }
$$

Lythrum junceum Banks \& Sol.

Lythrum portula (L.) D.A. Webb

Mentha pulegium $\mathrm{L}$

Mentha suaveolens Ehrh.

Montia minor C.C.Gmel. subsp. chondrosperma (Fenzl)

$$
\text { Walters }
$$

Myosotis welwitschii Boiss. \&$$
\text { Reut. }
$$

Nardus stricta L.

Nasturtium officinale R.Br.

Oenanthe lachenalii C.C.Gmel.

Ornithopus pinnatus (Miller)$$
\text { Druce }
$$

Panicum repens $\mathrm{L}$.

Parentucellia viscosa (L.) Caruel

Paspalum distichum $\mathrm{L}$.

Phragmites australis (Cav.) Steud.

Plantago coronopus $\mathrm{L}$

Роа аппиа $\mathrm{L}$.

Polypogon monspeliensis (L.)

Destamogeton polygonifolius
Pot

$$
\text { Pourr. }
$$


Potentilla erecta (L.) Räuschel

Prunella vulgaris $\mathrm{L}$.

Prunus lusitanica $\mathrm{L}$.

Pycreus flavescens (L.) P.Beauv.

$$
\text { ex Rchb. }
$$

Quercus canariensis Willd.

Radiola linoides Roth.

Ranunculus baudotii Godr.

Ranunculus bulbosus $\mathrm{L}$.

Ranunculus ficaria $\mathrm{L}$.

Ranunculus flammula $\mathrm{L}$.

Ranunculus hederaceus L

Ranunculus ophioglossifolius Vill.

Ranunculus tripartitus DC.

Rubus ulmifolius Schott.

Rumex conglomeratus Murray

Rumex pulcher $\mathrm{L}$.

Salix atrocinerea Brot.

Salix pedicellata Desf.

Samolus valerandi $\mathrm{L}$.

Scrophularia auriculata Loefl. ex

Serapias lingua $\mathrm{L}$.

Serapias strictiflora Welw. ex Da

$$
\text { Veiga }
$$

Sherardia arvensis $\mathrm{L}$.

Silene laeta (Aiton) Godr.

Solenopsis laurentia (L.) C.Presl.

Sparganium erectum $\mathrm{L}$.

Tolpis barbata (L.) Gaertn.

Trifolium filiforme $\mathrm{L}$

Trifolium michelianum Savi

Trifolium nigrescens Viv.

Trifolium resupinatum $\mathrm{L}$

Trifolium strictum $\mathrm{L}$.

Trifolium subterraneum $\mathrm{L}$.

Typha latifolia $\mathrm{L}$.

Utricularia australis $\mathrm{R} \mathrm{Br}$

Verbena supina $\mathrm{L}$.

Veronica anagalloides Guss.

Vulpia myur

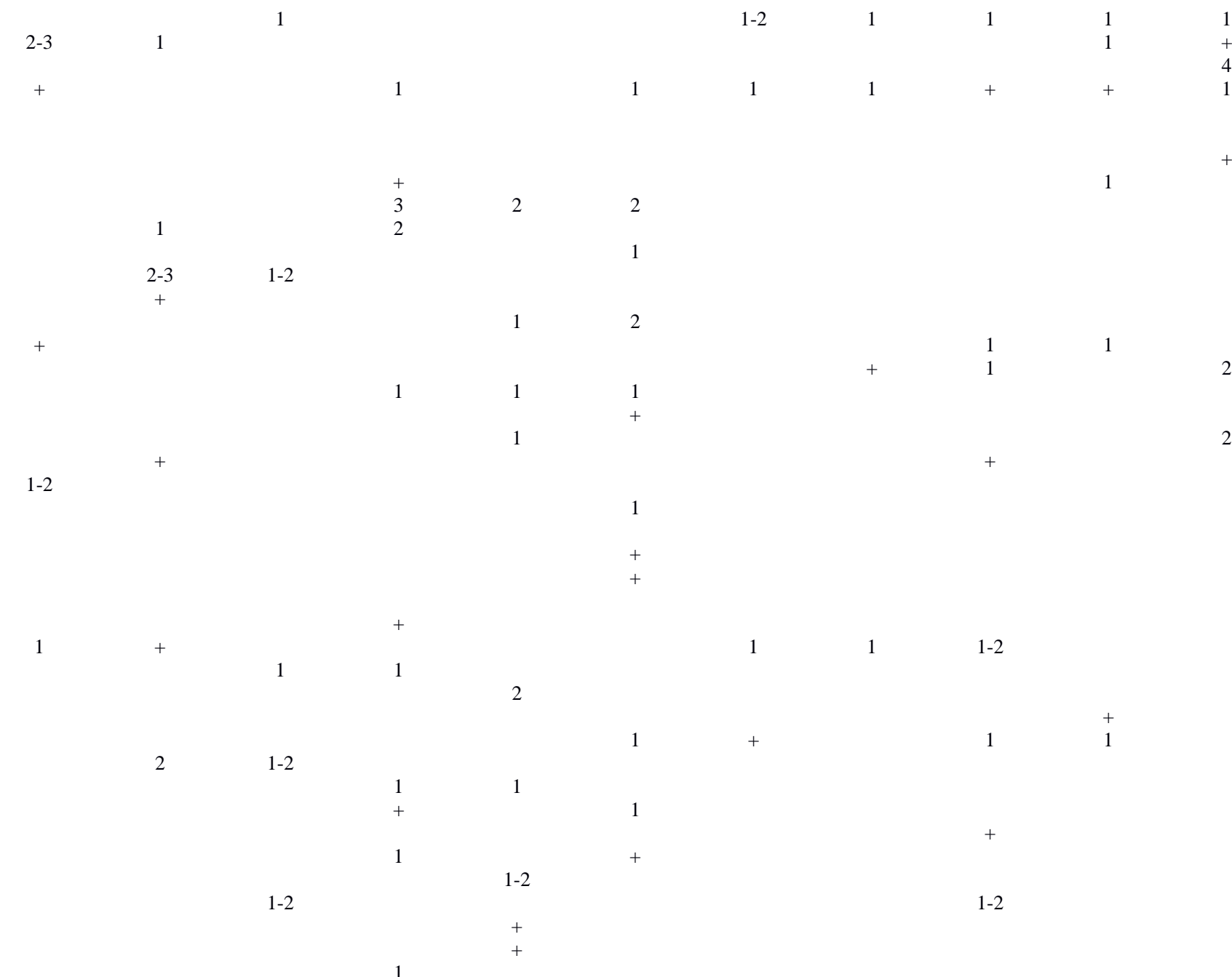

Table 2. Vegetation surveys in 13 wetlands of the Jebala Range. The signification of site codes is given Table 1. 


\begin{tabular}{|c|c|c|c|c|c|c|c|c|c|c|c|c|c|c|}
\hline \multirow[t]{2}{*}{ Taxon } & \multirow{2}{*}{$\begin{array}{l}\text { Number } \\
\text { of slides }\end{array}$} & \multirow{2}{*}{$\begin{array}{l}\text { Number of } \\
\text { measured } \\
\text { grains }\end{array}$} & \multicolumn{2}{|c|}{ Polar length $(\mu)$} & \multicolumn{4}{|c|}{ Equatorial length $(\mu)$} & \multicolumn{3}{|c|}{ Annulus diameter $(\mu)$} & \multicolumn{3}{|c|}{ Pore diameter $(\mu)$} \\
\hline & & & Mean & Min & Max & Mean & Min & $\operatorname{Max}$ & Mean & Min & Max & Mean & Min & Max \\
\hline \multicolumn{14}{|l|}{ Avena barbata } & 6.0 \\
\hline Avena sativa & 1 & 34 & $47.2 \pm 0.8$ & 41.0 & 53.0 & $43.0 \pm 0.9$ & 39.0 & 52.0 & $11.9 \pm 0.2$ & 10.5 & 13.0 & $5.4 \pm 0.2$ & 4.3 & 7.4 \\
\hline \multicolumn{15}{|l|}{ Bromopsis inermis } \\
\hline subsp. inermis & 1 & 20 & $41.6 \pm 1.1$ & 37.0 & 47.0 & $38.2 \pm 0.6$ & 35.0 & 41.0 & $9.8 \pm 0.3$ & 8.3 & 11.6 & $5.0 \pm 0.2$ & 4.1 & 5.9 \\
\hline Dactylis glomerata & 1 & 8 & $33.0 \pm 2.4$ & 28.0 & 42.0 & $31.0 \pm 1.6$ & 27.0 & 35.0 & $6.7 \pm 0.3$ & 6.0 & 7.5 & $3.4 \pm 0.1$ & 3.1 & 3.8 \\
\hline Elytrigia campestris & 1 & 18 & $39.3 \pm 0.8$ & 35.0 & 42.0 & $36.1 \pm 0.9$ & 32.0 & 40.0 & $9.5 \pm 0.4$ & 7.6 & 11.0 & $4.5 \pm 0.2$ & 3.7 & 5.5 \\
\hline Glyceria fluitans & 2 & 43 & $45.0 \pm 0.8$ & 40.2 & 55.3 & $42.5 \pm 0.6$ & 38.2 & 48.1 & $13.8 \pm 0.4$ & 11.1 & 18.2 & $6.5 \pm 0.3$ & 4.8 & 10.7 \\
\hline Glyceria notata & 2 & 49 & $47.8 \pm 0.6$ & 40.9 & 52.7 & $45.1 \pm 0.8$ & 37.9 & 52.0 & $12.0 \pm 0.6$ & 6.7 & 17.7 & $6.1 \pm 0.5$ & 3.1 & 9.9 \\
\hline Hordeum brevisubulatum & 1 & 39 & $45.7 \pm 0.6$ & 42.0 & 50.0 & $39.4 \pm 0.7$ & 35.0 & 44.0 & $11.7 \pm 0.2$ & 10.5 & 13.2 & $4.6 \pm 0.1$ & 3.6 & 5.6 \\
\hline \multicolumn{15}{|l|}{ Hordeum vulgare } \\
\hline subsp. distichon & 2 & 18 & $56.3 \pm 2.3$ & 45.9 & 67.5 & $49.2 \pm 3.1$ & 41.8 & 66.7 & $14.1 \pm 0.8$ & 11.1 & 17.5 & $5.1 \pm 0.5$ & 3.4 & 7.5 \\
\hline Leymus condensatus & 1 & 30 & $45.5 \pm 0.9$ & 42.0 & 51.0 & $42.0 \pm 0.9$ & 37.0 & 48.0 & $9.8 \pm 0.2$ & 7.6 & 11.3 & $5.0 \pm 0.1$ & 4.0 & 6.2 \\
\hline Phragmites communis & 1 & 29 & $40.7 \pm 1.4$ & 33.0 & 50.0 & $36.5 \pm 1.3$ & 26.6 & 44.0 & $9.7 \pm 0.3$ & 8.1 & 12.0 & $4.5 \pm 0.2$ & 3.6 & 6.6 \\
\hline Schedonorus arundinaceus & 1 & 12 & $36.9 \pm 2.7$ & 24.0 & 45.0 & $34.2 \pm 2.1$ & 24.0 & 41.0 & $7.0 \pm 0.5$ & 5.3 & 8.9 & $3.4 \pm 0.3$ & 2.5 & 4.3 \\
\hline Secale cereale & 2 & 28 & $82.1 \pm 3.3$ & 51.0 & 97.0 & $68.2 \pm 3.6$ & 42.0 & 87.0 & $16.8 \pm 0.8$ & 11.2 & 22.0 & $6.9 \pm 0.3$ & 4.3 & 9.0 \\
\hline Thinopyrum elongatum & 1 & 27 & $44.8 \pm 1.2$ & 36.0 & 51.0 & $41.6 \pm 1.0$ & 36.0 & 48.0 & $10.3 \pm 0.3$ & 7.8 & 12.0 & $4.5 \pm 0.2$ & 3.3 & 5.7 \\
\hline \multicolumn{15}{|l|}{ Triticum aestivum } \\
\hline subsp. aestivum & 3 & 22 & $72.0 \pm 1.7$ & 61.0 & 79.0 & $67.0 \pm 2.3$ & 52.0 & 77.0 & $19.0 \pm 0.3$ & 16.9 & 21.1 & $8.4 \pm 0.4$ & 7.1 & 11.2 \\
\hline subsp. spelta & 4 & 36 & $68.9 \pm 1.3$ & 56.0 & 80.0 & $63.0 \pm 1.2$ & 54.0 & 70.0 & $17.2 \pm 0.4$ & 14.7 & 20.5 & $7.4 \pm 0.3$ & 5.9 & 10.2 \\
\hline Triticum compactum & 1 & 30 & $80.3 \pm 2.3$ & 65.0 & 98.0 & $70.2 \pm 1.7$ & 57.4 & 78.0 & $21.6 \pm 0.7$ & 16.8 & 27.8 & $10.2 \pm 0.4$ & 7.8 & 14.4 \\
\hline \multicolumn{15}{|l|}{ Triticum turgidum } \\
\hline subsp. dicoccon & 1 & 29 & $.5 \pm 1.0$ & 63.0 & 75.0 & $63.8 \pm 1.4$ & 55.0 & 73.0 & $17.4 \pm 0.3$ & 13.8 & 19.8 & $6.1 \pm 0.2$ & 4.6 & 7.2 \\
\hline subsp. durum & 4 & 38 & $65.0 \pm 2.0$ & 47.0 & 85.0 & $59.6 \pm 2.0$ & 46.0 & 79.0 & $15.9 \pm 0.4$ & 13.1 & 18.9 & $6.3 \pm 0.2$ & 4.2 & 7.9 \\
\hline subsp. turgidum & 1 & 16 & $80.0 \pm 4.5$ & 56.6 & 95.8 & $72.5 \pm 4.1$ & 52.8 & 89.1 & $21.5 \pm 1.5$ & 15.6 & 28.2 & $8.3 \pm 0.8$ & 5.9 & 12.4 \\
\hline Zea mays & 1 & 15 & $126.9 \pm 4.3$ & 108.0 & 148.0 & $116.5 \pm 3.2$ & 106.0 & 130.0 & $23.5 \pm 0.6$ & 22.0 & 27.4 & $8.5 \pm 0.7$ & 6.4 & 10.9 \\
\hline
\end{tabular}

Table 3. Biometric data of selected Poaceae pollen grains from the pollen collection of ISEM, Univ. Montpellier (France). Pollen is mounted in glycerol. Cultivated taxa are noted in bold. Mean values are given with the standard error. 


\begin{tabular}{|c|c|c|c|c|c|c|c|}
\hline \multirow{2}{*}{$\begin{array}{l}\text { Representation } \\
\text { Strongly associated taxa }\end{array}$} & \multirow{2}{*}{$\begin{array}{l}\text { Pollen taxa } \\
\text { Alisma-type }\end{array}$} & \multicolumn{2}{|l|}{$\mathbf{A}$} & \multicolumn{2}{|l|}{$\mathbf{U}$} & \multicolumn{2}{|l|}{$\mathbf{O}$} \\
\hline & & 100 & $(82-100)$ & 0 & $(0-18)$ & 0 & $(0-18)$ \\
\hline & Asteroideae & 67 & $(43-84)$ & 0 & $(0-25)$ & 33 & $(16-57)$ \\
\hline & Cyperaceae & 100 & $(82-100)$ & 0 & $(0-18)$ & 0 & $(0-18)$ \\
\hline & Lobelia & 67 & $(25-92)$ & 0 & $(0-57)$ & 33 & $(8-75)$ \\
\hline & Lysimachia tenella-type & 67 & $(40-86)$ & 14 & $(3-45)$ & 25 & $(9-54)$ \\
\hline & Poaceae & 92 & $(70-98)$ & 0 & $(0-20)$ & 8 & $(2-30)$ \\
\hline & Ranunculus-type & 91 & $(68-98)$ & 0 & $(0-21)$ & 9 & $(2-32)$ \\
\hline & Rubiaceae & 67 & $(40-86)$ & 0 & $(0-31)$ & 33 & $(14-60$ \\
\hline & Sphagnum & 100 & $(72-100)$ & 0 & $(0-28)$ & 0 & $(0-28)$ \\
\hline \multirow[t]{9}{*}{ Associated taxa } & Apiaceae & 55 & $(32-76)$ & 14 & $(3-45)$ & 40 & $(19-65)$ \\
\hline & Cicendia/Exaculum & 57 & $(29-81)$ & 20 & $(5-56)$ & 33 & $(12-65)$ \\
\hline & Ilex & 50 & $(12-88)$ & 0 & $(0-73)$ & 50 & $(12-88$ \\
\hline & Juncaceae & 50 & $(29-71)$ & 45 & $(24-68)$ & 14 & $(3-45)$ \\
\hline & Lotus-type & 64 & $(39-82)$ & 36 & $(18-61)$ & 0 & $(0-28)$ \\
\hline & Plantago coronopus-type & 50 & $(29-71)$ & 0 & $(0-31)$ & 50 & (29-71) \\
\hline & Potamogeton-type & 50 & $(25-75)$ & 33 & $(12-65)$ & 33 & $(12-65)$ \\
\hline & Potentilla & 56 & $(30-78)$ & 29 & $(10-59)$ & 29 & $(10-59$ \\
\hline & Samolus & 50 & $(12-88)$ & 0 & $(0-73)$ & 50 & $(12-88$ \\
\hline \multirow[t]{9}{*}{ Weakly associated taxa } & Callitriche & 11 & $(3-38)$ & 80 & $(44-95)$ & 80 & $(44-95$ \\
\hline & Dryopteris-type & 20 & $(5-56)$ & 50 & $(12-88)$ & 75 & $(36-94)$ \\
\hline & Frangula & 17 & $(4-50)$ & 50 & $(12-88)$ & 80 & $(44-95)$ \\
\hline & Genista-type & 22 & $(8-50)$ & 50 & $(18-82)$ & 71 & $(41-90)$ \\
\hline & Gratiola & 25 & $(6-64)$ & 50 & $(12-88)$ & 67 & $(25-92)$ \\
\hline & Illecebrum/Paronychia & 14 & $(3-45)$ & 67 & $(25-92)$ & 80 & $(44-95$ \\
\hline & Lysimachia arvensis-type & 0 & $(0-57)$ & 100 & $(27-100)$ & 100 & $(27-101$ \\
\hline & Prunus-type & 14 & $(3-45)$ & 67 & $(25-92)$ & 80 & $(44-95)$ \\
\hline & Salix & 18 & $(6-43)$ & 50 & $(18-82)$ & 78 & $(50-92)$ \\
\hline \multirow[t]{18}{*}{ Over-represented taxa } & Alnus glutinosa-type & 25 & $(9-54)$ & 0 & $(0-57)$ & 75 & (46-91) \\
\hline & Brassicaceae & 25 & $(10-49)$ & 0 & $(0-47)$ & 75 & $(51-90)$ \\
\hline & Calluna & 20 & $(5-56)$ & 0 & $(0-73)$ & 80 & $(44-95$ \\
\hline & Cerealia-type & 33 & $(16-57)$ & 0 & $(0-40)$ & 67 & $(43-84)$ \\
\hline & Cichorioideae & 17 & $(6-40)$ & 0 & $(0-57)$ & 83 & $(60-94)$ \\
\hline & Cistus & 17 & $(6-40)$ & 0 & $(0-57)$ & 83 & $(60-94)$ \\
\hline & Erica-type & 42 & $(22-64)$ & 0 & $(0-35)$ & 58 & $(36-78)$ \\
\hline & Fabaceae & 22 & $(8-50)$ & 0 & $(0-57)$ & 78 & $(50-92)$ \\
\hline & Hedera & 20 & $(5-56)$ & 0 & $(0-73)$ & 80 & $(44-95$ \\
\hline & Isoetes & 43 & $(19-71)$ & 0 & $(0-47)$ & 57 & $(29-81)$ \\
\hline & Lythrum salicaria & 0 & $(0-57)$ & 0 & $(0-57)$ & 100 & $(43-101$ \\
\hline & Myriophyllum alterniflorum & 0 & $(0-35)$ & 0 & $(0-35)$ & 100 & $(65-101$ \\
\hline & Nymphaea & 0 & $(0-73)$ & 0 & $(0-73)$ & 100 & $(27-101$ \\
\hline & Ophioglossum & 0 & $(0-57)$ & 0 & $(0-57)$ & 100 & $(43-101$ \\
\hline & Osmunda & 0 & $(0-57)$ & 0 & $(0-57)$ & 100 & $(43-101$ \\
\hline & Quercus canariensis-type & 8 & $(2-30)$ & 0 & $(0-73)$ & 92 & $(70-98$ \\
\hline & Radiola & 0 & $(0-57)$ & 0 & $(0-57)$ & 100 & $(43-10 i$ \\
\hline & Sparganium/Typha & 33 & $(8-75)$ & 0 & $(0-73)$ & 67 & $(25-92)$ \\
\hline
\end{tabular}

Table 4. Indices (\%) of association (A), under-representation (U) and over-representation (O) for taxa present in both plant and pollen datasets in the Jebala Range wetlands, with $90 \%$ confidence intervals given into brackets. See text for explanations. 


\begin{tabular}{|c|c|c|c|c|c|c|c|}
\hline Site & Core & $\begin{array}{l}\text { Depth } \\
\text { (cm) }\end{array}$ & $\begin{array}{l}\text { Code } \\
\text { laboratory }\end{array}$ & $\begin{array}{l}\text { Age }{ }^{14} \mathrm{C} \\
\text { (BP) }\end{array}$ & $\begin{array}{l}\text { Calendar age } \\
2 \sigma(\text { cal. BP) }\end{array}$ & Dated material & Reference \\
\hline \multirow[t]{10}{*}{ Bartete } & \multirow[t]{9}{*}{ BAR1bis } & $49-50$ & Poz-82703 & $55 \pm 30$ & Modern & Sediment & This study \\
\hline & & $50-51$ & Poz-87231 & $55 \pm 30$ & Modern & Sediment & - \\
\hline & & $61-62$ & Poz-94942 & $2485 \pm 30$ & $2720-2430$ & Sediment & - \\
\hline & & $81-82$ & Poz-94943 & $4000 \pm 35$ & $4570-4410$ & Sediment & - \\
\hline & & $99-100$ & Poz-82921 & $3795 \pm 35$ & $4350-4010$ & Sediment & - \\
\hline & & $149-150$ & Poz-82922 & $5775 \pm 30$ & $6660-6490$ & Sediment & - \\
\hline & & 190 & Poz-51919 & $2350 \pm 35$ & $2660-2320$ & Charcoal: $c f$. Lamiaceae & $\begin{array}{l}\text { Muller et al., } \\
2015\end{array}$ \\
\hline & & 199-200 & Poz-82923 & $8290 \pm 50$ & $9450-9040$ & Sediment & This study \\
\hline & & $247-248$ & Poz-82924 & $\begin{array}{l}11040 \pm \\
70\end{array}$ & $13100-12780$ & Sediment & - \\
\hline & $\begin{array}{l}\text { BAR3- } \\
1977\end{array}$ & $125-130$ & Lv-635 & $1010 \pm 50$ & $1050-790$ & Sediment & Reille, 1977 \\
\hline \multirow[t]{5}{*}{ Maison Forestière-1 } & \multirow[t]{5}{*}{ MF1b } & $35-36$ & Poz-61157 & $315 \pm 30$ & $460-300$ & Sediment & $\begin{array}{l}\text { Muller et al., } \\
2015\end{array}$ \\
\hline & & 65 & Poz-51918 & $2060 \pm 30$ & $2110-1930$ & $\begin{array}{l}\text { Charcoal: Frangula } \\
\text { alnus }\end{array}$ & - \\
\hline & & $83-84$ & Poz-57995 & $2125 \pm 30$ & $2290-2000$ & Sediment & - \\
\hline & & 117 & Poz-51917 & $\begin{array}{l}11070 \pm \\
60\end{array}$ & $13100-12840$ & $\begin{array}{l}\text { Charcoal: Deciduous } \\
\text { Quercus }\end{array}$ & - \\
\hline & & $\begin{array}{l}131.5- \\
132\end{array}$ & Poz-57997 & $4480 \pm 60$ & $5310-4880$ & Sediment & - \\
\hline \multirow[t]{4}{*}{ Maison Forestière-3 } & \multirow[t]{4}{*}{ MF3 } & $95-96$ & Poz-76701 & $1040 \pm 30$ & $1050-840$ & Sediment & This study \\
\hline & & $200-201$ & Poz-76703 & $2440 \pm 30$ & $2700-2360$ & Sediment & - \\
\hline & & $301-302$ & Poz-80990 & $3375 \pm 35$ & $3690-3490$ & Sediment & - \\
\hline & & $400-401$ & Poz-76704 & $3980 \pm 35$ & $4530-4300$ & Sediment & - \\
\hline
\end{tabular}

Table 5. Radiocarbon ages of the studied sites (BAR, MF1b and MF3) and basal ages of other sites in the Jebala Range (from Reille 1977; Cheddadi et al., 2015, 2016). Ages highlighted in grey are rejected. 

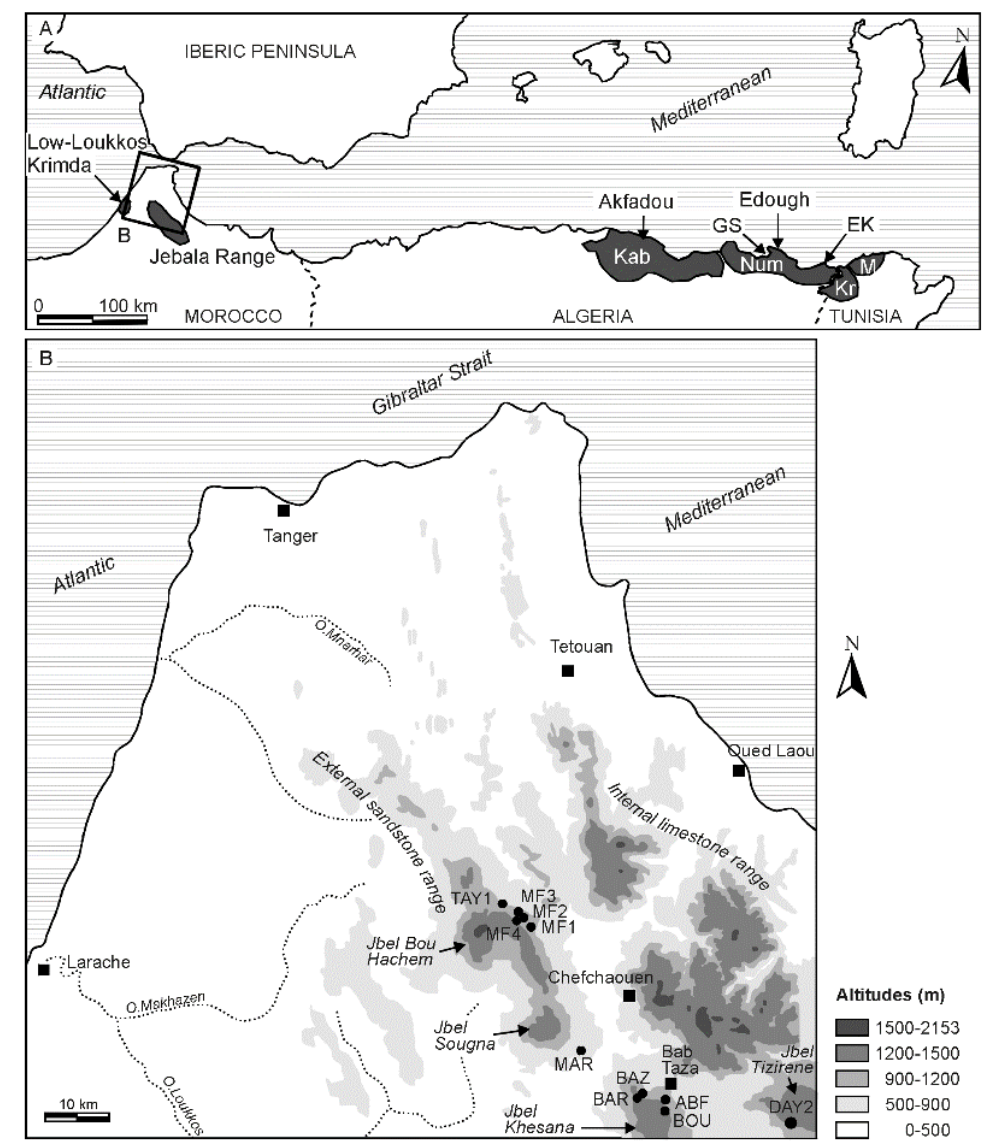

Figure 1. Location of studied regions and sites. (A): North African regions harbouring peatforming wetlands. EK, El Kala National Park; GS, Guerbès-Senhadja wetland complex; Kab, Kabylia; Kr, Kroumiria; M, Mogods; Num, Numidia. (B): Reliefs and studied sites of Northern Morocco

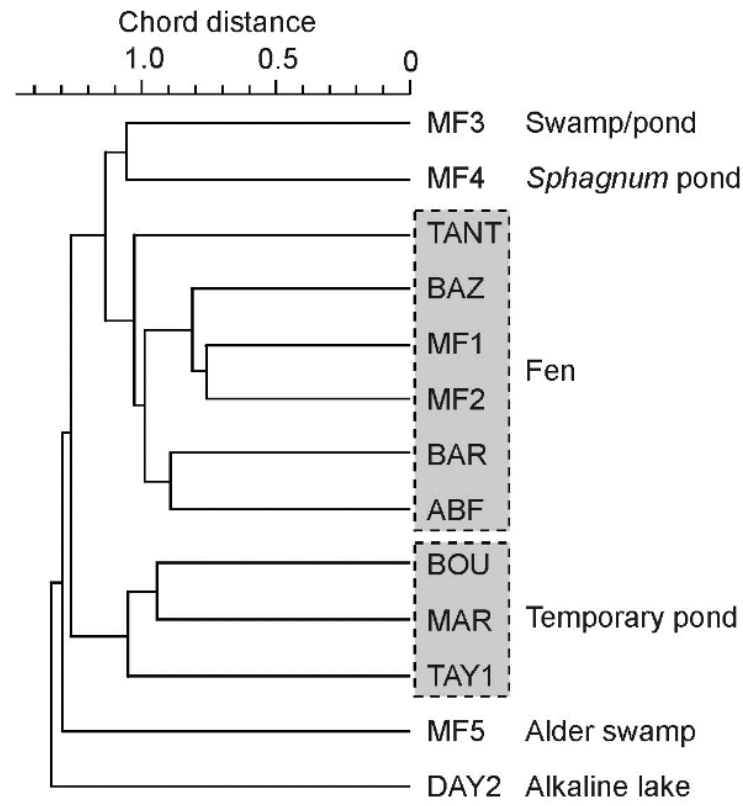

Figure 2. Ascendant hierarchical classification performed on phytosociological relevés (13 sites, 80 species) 


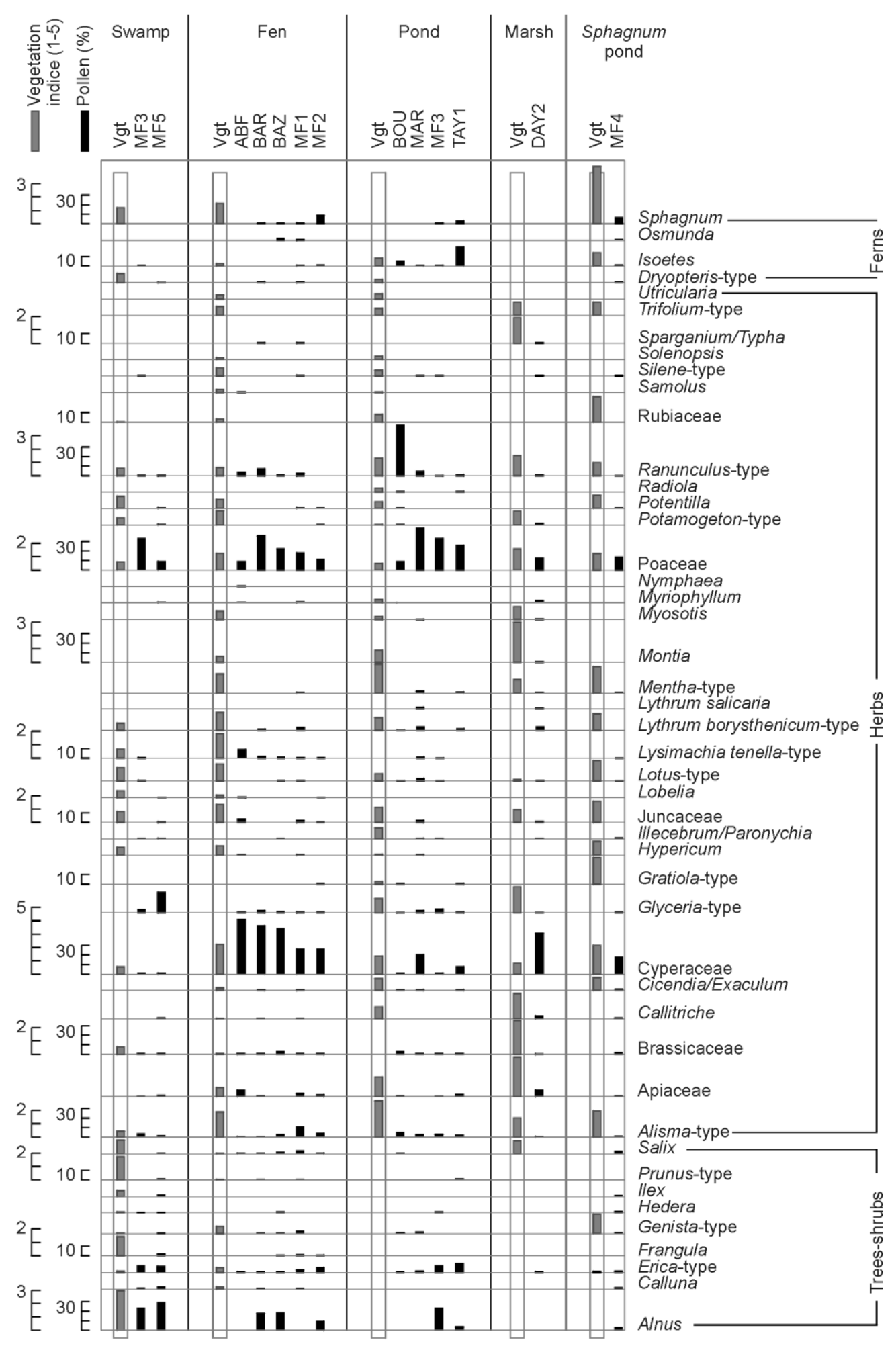

Figure 3. Surface percentage pollen diagram of hydrophytic taxa. Sites are grouped according to the classification in Figure 2. Grey histograms noted Vgt (in grey frames) correspond to mean abundance-dominance indices of vegetation surveys (1-5). Pollen percentages are calculated on pollen sums including terrestrial taxa but excluding ferns. 

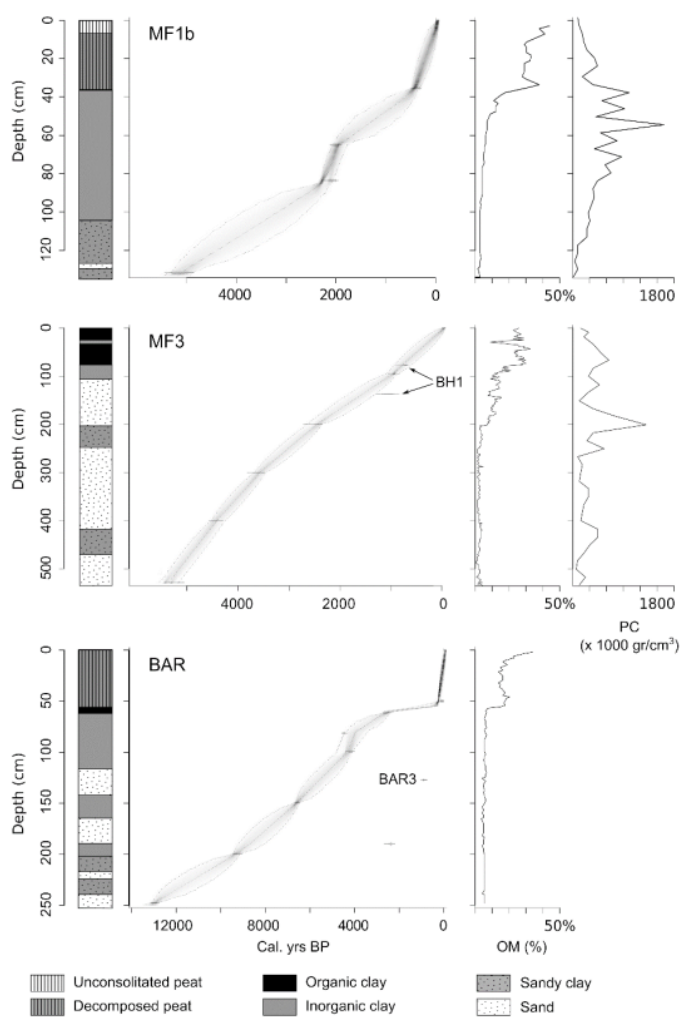

Figure 4. Age-depth models and content of organic matter (OM, \%) of BAR, MF1b and MF3 cores and pollen concentrations (PC, x $1000 \mathrm{gr} / \mathrm{cm}^{3}$ ) of MF1b and MF3 cores. The ages in red are from other cores previously taken in the same wetlands (Reille 1977).

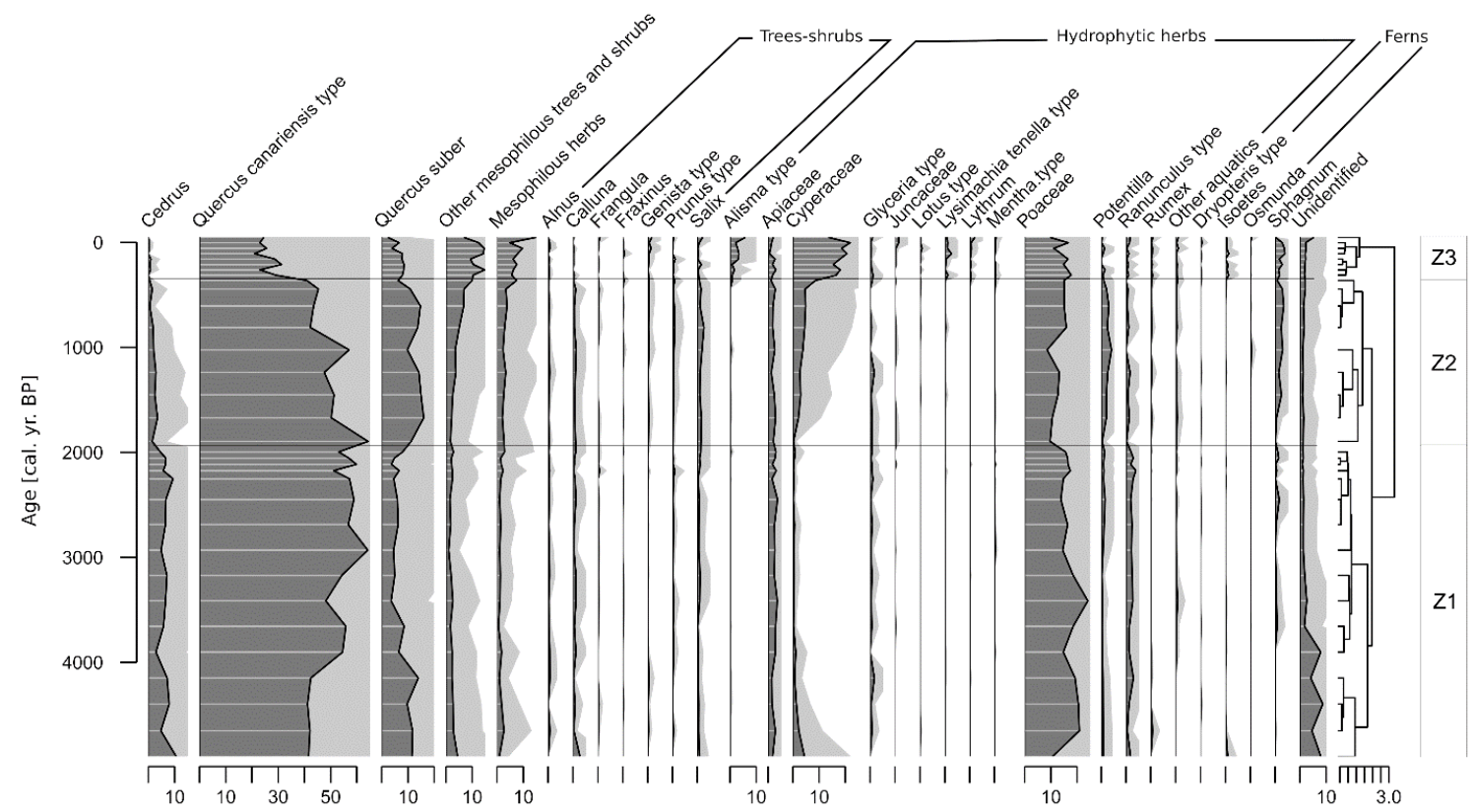

Figure 5. Local pollen percentage diagram of MF1b. Y axis is in years cal. BP. For each curve, is given the 5-fold exaggerated curve. 


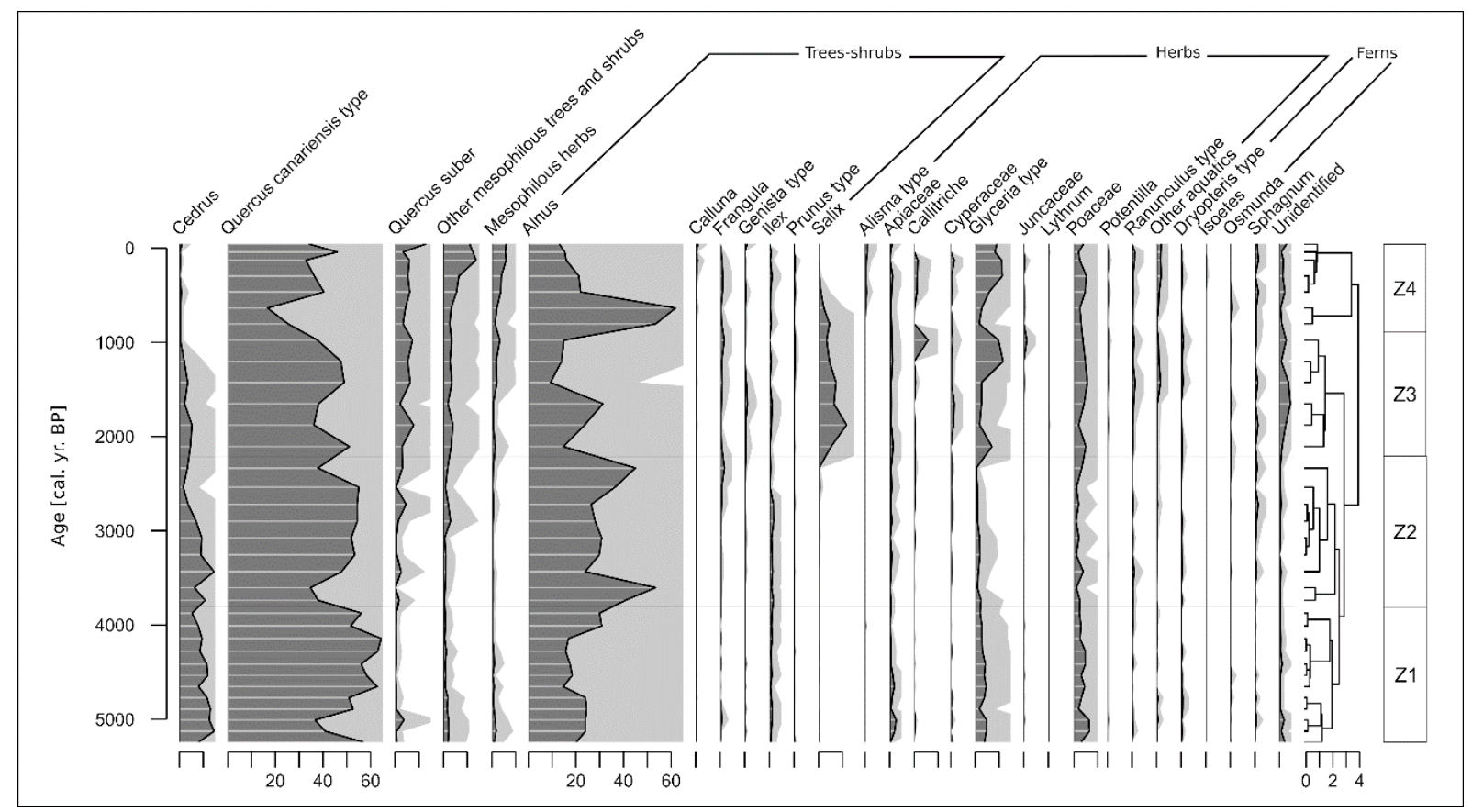

Figure 6. Local pollen diagram of MF3. Y axis is in years cal. BP. For each curve, is given the 5-fold exaggerated curve.

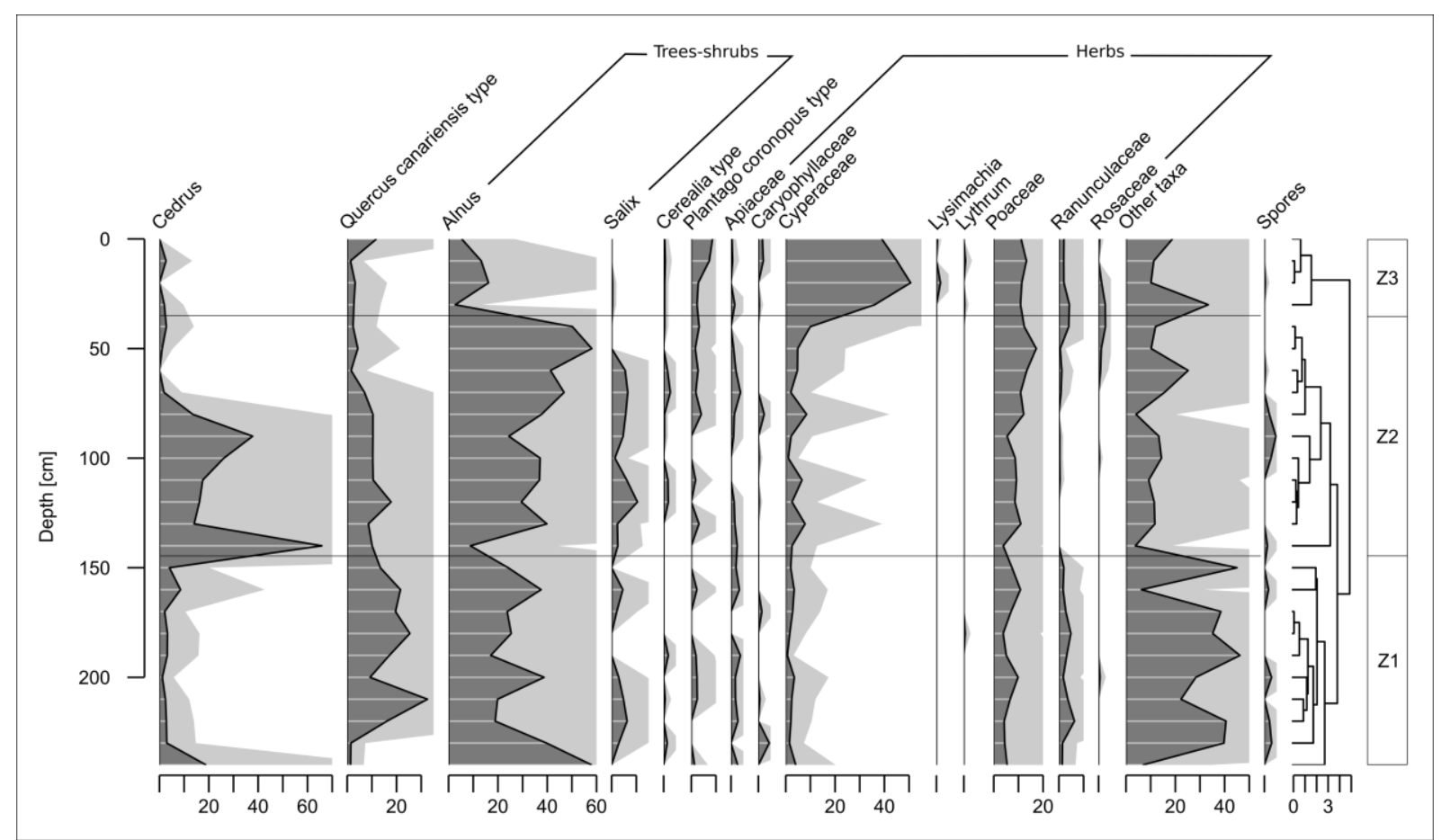

Figure 7. Local pollen diagram of BAR (from Reille 1977). Y axis is in cm. For each curve, is given the 5-fold exaggerated curve. 